\title{
Ernst von Aster ve Çağdaș Felsefe Ders Notları
}

\section{Ernst von Aster and Contemporary Philosophy Lecture Notes}

\author{
OSMAN ÖZKUL \\ Sakarya University \\ YASIN ȘAHIN \\ Sakarya University
}

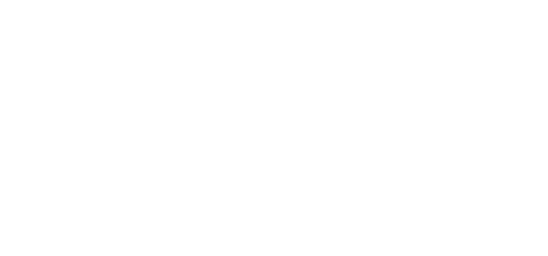

Received: 28.09.2018 | Accepted: I0.I2.2018

\begin{abstract}
This study is composed of short biographic information about Ernst Von Aster, 2oth Century German historian of philosophy, and the lecture notes about "Contemporary Philosophy" that is given by him at Istanbul University Faculty of Literature Philosophy Department in the 1943-1944 academic period. The text which is the lecture notes taken by Cahit Tanyol, a student at the Philosophy Department in the above-mentioned period, in Ottoman Turkish has been translated into Latin alphabet and made ready to be published. Lecture notes are started with the Descartes philosophy, especially his existence approach. Then the views of Descartes and Newton about universe and mechanics are compared. Right after the relations between Newton physics and Kant philosophy are examined. Subsequently, Kant metaphysics and the philosophy of Brentano are compared with each other. After the comparison between Neo-Kantianism and Schelling, the relation between Kant and Husserl is examined. On the other hand, time and space in the Heidegger's ontology are dealt with. Also, the existing approach in Descartes and Heidegger is investigated. Lastly, Vitalism of Hans Driesch and Spiritualism of Bergson are dealt with. The lecture notes end with the New Positivism after comparison is made between evolution approaches of Bergson and Darwin.
\end{abstract}

Keywords: Ernst von Aster, lecture notes, contemporary philosophy, physics, existence.

(C) Özkul, O. \& Șahin, Y. (2019). Ernst von Aster ve Çağdaş Felsefe Ders Notları. Beytulbikme An International fournal of Philosophy, 9 (I), 23I-277. 


\section{Ernst von Aster}

Ernst von Aster (I880-I948), tarihinde birçok dahi yetiștirmiș olan çağdaș Alman düșünürüdür. II. Dünya Savașı sırasında Alman Nasyonalizminin yol açtığı zulümlere taraftar olmayarak Türkiye'ye gelmiș ve ömrünün sonuna kadar da İstanbul Üniversitesinin çeșitli fakültelerinde dersler, konferanslar vermiș ve yazılar yayınlamıștır. Hayatının olgunluk çă̆ını İstanbul Üniversitesi'nin Edebiyat Fakültesinde Felsefe Tarihi; Hukuk Fakültesinde Hukuk Felsefesi; İktisat Fakültesinde de Metodoloji Felsefesi dersleri vererek geçirmiștir. Bu süre içinde birçok Türk gencini aydınlatmaya çalıșmıș hem ilmiyle hem de ahlakıyla, akademik çevresine örnek bir șahsiyet olmuștur.

Genel olarak İstanbul üniversitesine, daha özelde ise felsefe bölümünün hoca kadrosunun yetișmesine ve kimliğine von Aster çok önemli katkılar yapmıștır. Bölümde verdiği felsefe tarihi dersleri yanında, ahlak, insan ve bilim felsefesi konularında da makaleler yayınlamıs, konferanslar vermiștir. I7 adet Almanca eserinin dıșında Türkiye'de bulunduğu sürede I9 adet kitap ve makale yayınlamıs, 9 da konferans vermiștir. Bunlardan așağıda takdim edeceğimiz çalıșmasına bir alt yapı mahiyetinde Newton'dan Einstein'a gelinceye kadar fizik alanındaki teorilerin kritiğini yaptı̆̆ı "Fizik ve Felsefe" (von Aster, I949) makalesi çok önemli bir yere sahiptir.

I9. asrın son çeyreği ile 20. Asrın birinci yarısında yașamıs, olan von Aster, Almanya'da muhtelif felsefe ekollerinin birbirleriyle çarpıștığı dönemin yoğurduğu bir șahsiyettir. Bir yanda pozitivizm ve pozitivist yaklaşımcı psikolojizm, diğer tarafta ise Yeni Kantçılık var. Bunların yanı bașında Fenomenoloji de yeni kurulmakta olan bir cereyan bulunmaktadir. İște von Aster'in düșünce sistemi bu ekollerin arasında olușur.

Üniversite öğrenimine lise hocası olmak amacıyla, fizik ve biyoloji gibi pozitif bilimlerle bașlayan von Aster, öğreniminin sonunda fizikten devlet imtihanını verir. Fakat bu hakkını kullanmayarak Felsefe Okumaya bașlar. Kant hakkında hazırladığı doktora çalıșmasıyla da felsefe eğitimini bitirir. Felsefe çalıșmalarında, daha önce almış olduğu fizik ve biyoloji bilimlerinin birikimlerinin etkilerini görmek mümkündür.

Nitekim kendisiyle benzer özellikleri tașıan Lipps ve Cornelius gibi 
Psikolojistlerin yanında çalıșır. Bu filozoflardan kendisi gibi tabiat bilimlerinden (kimya) bașlayıp, felsefeye geçmiș olan Cornelius onu daha çok etkisinde bırakmıștır. Mesela, bilgimizin kaynağı probleminde Cornelius, fenomenal dünyanın bizdeki șuur muhtevaları tarafından olușturulduğunu savunur. Bu anlamda da kendisinin felsefesinin bir idealizm olduğunu söyler.

Von Aster gerek hayat felsefesinde gerekse diğer felsefi problemlere yaklașımında hocasına yaklașır. Mesela Bilgi, ancak varlı̆̆ın fenomenal tarafına aittir. Çünkü bize doğrudan doğruya verilen, ancak șuur muhtevalarıdır. Varlığın bizatihi bir tarafı olsa bile, bunu ispat edemeyiz; ancak böyle olduğu hakkında bir kanaatimiz vardır ve bizatihi varlık, sırf bu kanaatin neticesidir. Von Aster' e göre felsefede problemleri birbirinden ayıran esaslı "sınır kavramları " vardır. Bütün izahlar bu kavramların arasına aittir. Fakat bizzat onlar her türlü izahtan kaçarlar. Onlar düșünce tarihinin bașlarından beri konulmuș oldukları halde haklarında kandırıcı hiçbir cevap bulunamamıștır. Bu problemlerden birincisi varlık, ikincisi șuurdur. Bir șey niçin vardır? sorusuna cevap veremeyiz, onu olduğu gibi kabule mecburuz. Nitekim șuurumuz niçin vardır? Ve șuurun özü nedir? Sorusu da bunlardandır. Biz süje ve obje ikiliğinin ancak șuur içinde tasavvur edildiğini biliyoruz. Fakat bizzat şuuru çözemiyoruz. (Ülken, I949: 58)

Von Aster'in etik konusundaki düșünceleri ise büyük Alman düșünürü Kant'dan mülhemdir. Ona göre Kant'ın ahlak görüșünden üstün ve daha iyi temellendirilmiș bir ahlak felsefesi tasavvur edilemez. Kant'in görüșleri psikoloji bakımından temellendirilmelidir. Ĕger bu iddia realize edilebilirse, yani pratiğe dönüștürülebilirse, bundan daha mükemmel bir ahlak sistemi düșünülemez. (Tanyol, I943-44) Bu düșünceler, onun Kant'a olan bağlılığının ne kadar güçlü olduğunu göstermektedir.

Von Aster'in felsefe tarihi yöntemine gelince, bu konuda Türkçe yayınlanan "Felsefe Taribi Dersleri" eserinde son derece objektif bir yaklașım görülür. Bir filozofu ve düșüncelerini anlatırken, adeta bütün varlı̆̆ıyla o filozofun kișiliğine bürünür ve sisteminin içine girer; adeta yalnız onun zaviyesinden konușur. Bu da onun sadece sistematik değil; aynı zamanda objektif bir felsefe tarihçisi olduğunu gösterir.

Her dersten önce, geçen dersin ana hatlarıla hatırlanmasıyla konuya girer ve yeni konu ile olan bağı öyle ustalıkla kurar ki, yeni bir konuya 
geçildiği zor fark edilir. Onun ilkçağdan orta çağa, ortaçağdan, çağımız filozoflarına kadar filozoflar ve düşünceleri arsında kurduğu bağlantılar son derece vukuflu bir hoca olduğunu göstermektedir. Ona göre felsefe tarihi, bir takım olayları, bir takım hal tercümelerini, bir takım kanaatleri ardı ardına sıralayarak bildirmek demek değildir. Felsefe tarihi felsefenin problemlerinin anlamını kavrayabilmeyi, bu problemlerin tarihini izlemeyi de gerektirir. Bunun içindir ki, felsefe tarihi bir felsefe disiplinidir, hem dc felsefenin çok önemli bir disiplini!.. (von Aster, 2005: 5I)

Felsefe tarihi, aynı zamanda felsefe problematiğinin gelișme sürecini göstererek; bu gelișmenin içindeki mantıki düzeni kavramaya yarar. Bundan dolayı böyle bir felsefe tarihinin kendisi de aslında bir felsefe disiplinidir. Felsefe tarihi bize, felsefenin ne olduğunu, insan șuur ve kültürünün gelişmesinde felsefenin ne gibi bir yeri olduğunu gösterir. Bununla da felsefe tarihi, felsefe üzerine bir felsefe yapmak olur. Bu konuda öğrencisi Macit Gökberk, Onun felsefe tarihçiliğini daha ayrıntılı biçimde ele almaktadır.

Von Aster felsefe anlayıșını dile getirirken "Șimdiki Zaman Felsefesi" adlı eserinin önsözünde șöyle diyor: "Gerçek felsefe bir dialegesthai, bir konușma, bir soru ve cevaptır; cevabı, daima, en derin yerinden yakalayıp çürütmek isteyen bir șüphedir" ( Gökberk, 1949, ıo). Bu yaklaşımını felsefe tarihçiliğinde de yansıtan von Aster, bir filozofu anlatırken, onun ile bașka bir filozofu sorgulatır ve tartıștırır. Von Aster için felsefe tarihi felsefenin dıșında değil içindedir. Von Aster'in felsefe tarihinde kullandı̆̆ yöntemi ise, bir felsefe görüșünü içinde doğup serpildiği devrin manevî dokusundan türetmek isteyen "kültür tarihi metodu" değildir. Düșünürü ağırlık merkezi olarak alıp onun mahiyet ve alınyazısından dünyagörüșünü, felsefî yaratmalarını anlamağa çalıșan "biyografi metodu" da değildir." Von Aster için felsefe tarihi, felsefe problemlerinin gelişme sürecini gösteren, bu gelișmenin içindeki mantıkî düzeni kavratan bir felsefe disiplinidir. Felsefe tarihi bize, felsefenin ne olduğunu, insan șuur ve kültürünün gelișmesinde felsefenin ne gibi bir yeri olduğunu gösterir. Bununla da felsefe tarihi, felsefe üzerine bir felsefe yapmak olur" (Gökberk, I949: I6-I7)

Von Aster'in düșüncelerindeki bu özellik, Macit Gökberk tarafından kitaplaștırılmıș olan "Felsefe Tarihi Dersleri" (Gökberk, 1982) ve "Bilgi 
Teorisi ve Mantık" (von Aster, 1994) eserlerinde çok iyi gözlenebilir. Bu derslerin devamı olarak anlatmıș olduğu Kant Felsefesi ve Çă̆daș Felsefe ders notlarının da aynı șekilde olduğunu görürüz. Örneğin Kant'ı anlatırken; onun Newton gibi fizikçilerin düșünceleriyle, teorileriyle nasıl bir ilgi içinde olduğunu çok açık bir șekilde dile getirir. Kant, Newton'un mekanik ve iradi dünya ayrımını bir veri olarak kullanır. Ancak, Newton için mekanik, Kant için ise iradi âlem daha önemlidir. Çünkü zaman ve mekân dâhilinde tasavvur edilmiș varlıklar, nedensellik kanunlarına tabidir. Fakat insanda diğer bir âlem vardır ki; bu zamandan ve mekândan uzaktır. Yani, insan iki âlemi kușatmaktadır. Kant insana irade sahasını ayırıyor. Kant tabiat için sadece mekanik anlayıșı kabul ederken, insana özel bir anlam ve irade hürriyeti veriyor.

Walter Kranz, von Aster'in bir filozof ve bir düșünce ile ilișkisini şöyle anlatıyor: "Bir Demokritos ile bir Aristoteles, bir Hobbes ile bir Spinoza, bir Freud ile bir Brentano gibi birbirlerinden pek ayrı, hatta birbirine zıt șahsiyetleri tasvir kabiliyetinin kaynağı, onun zekâsının uyma kabiliyeti ve eğilir-bükülür olușudur. Onun söyledikleri daima birleșip canlı bir tablo meydana getiriyor. Bütün bir devrin karakterini göstermek yahut mantığın, ahlâkın, bilgi teorisinin öğretileri üzerine toplu bir bakıs, vermek gibi daha büyük ve güç bir vazife ile karșılaștığı zaman, zekâsının aydınlığı ona ana-çizgileri seçmek ve iyice anlașılır şekilde tasvir etmek için gerekli gücü veriyor. Von Aster; "Her bir feylesof șahsiyetin düșüncelerine bürünebilirim, yine de kendi felsefece görüș-noktamdan ayrılmam" derdi. (Kranz, I949: 8)

Von Aster'in derslerinin verdiği tadı kendisinden ders dinlemiș yüzlerce öğrencilerden mesela Bedia Akarsu anlatırken: "En çok faydaland1ğımız ve zevk aldığımız seminerler onun seminerleri İdi. Çünkü hepimiz hiç korkmadan, çekinmeden konuşurduk. Çünkü o, her düșünceye değer verir, dikkatle dinler, en kötü șekliyle anlattığımız düșüncelerimizi bile hemen eline alarak, evirir çevirir ve öyle yorumlardı ki, onun elinde düșüncelerimizin eriștiği açıklık ve değer kendimizi bile hayrete düșürürdü. Seminerden muhakkak kendi kendimize güvenimiz artmıș ve düșünmenin zevkine daha çok varmıs, olarak çıkardık” demektedir. (Akarsu, I949: I9)

Kișiliği ve davranıșlarıyla da tam bir bilgedir von Aster. Hitler'in zulmünden kaçarak, Türk gençlerinin aydınlanması yolunda fedakâr bir 
șekilde çalıșmıștır. Zulme ve baskıya karșı tepkisini, bütün ideolojileri reddederek kendi ülkesini terk etmek zorunda kalmıștır. Onunla birlikte felsefe bölümünde dersler vermiș olan Walther Kranz, barıșçılığını ve insaniyet-perverliğini anlatmak için şöyle der: "Von Aster, insanlık ve adalet için yaptığı mücadelesinden dolayı kahraman fakat zorlu dövüşçü Martin Luther'i değil, sessiz hümanist Rotterdam'lı Erasmus'u severdi. Temiz kalpli bu adam, kendini barıșın adamı olarak tanıtıyordu.” (Kranz, I949: 8)

Gerçek felsefenin bir konuşma, bir soru cevap olduğunu; cevabı daima en derin yerinden yakalayıp çürütmek biçiminde gören von Aster, bu sorgulayıcı tavrıyla; felsefe alanında materyalizm ve idealizm arasında bir sentez yapmaya çalıșır. Toplumsal düzlemde de, tam bir sentezci olarak yaklașan düșünür; dünyanın sulh ve sükûn içinde yașamasını ister; bunun mümkün olabileceğine de inanır. Von Aster'in bu düșünceleri günümüzdeki uygar dünyanın yüzlerce bilginlerinin yeni ölüm vasıtaları bulmak azmiyle çalıștıkları düșünülürse daha da anlam kazanmaktadır.

Vefatından sonra yayınlanan Felsefe Arkivinin sunuş yazısında Rektör Sıddık Sami Onar'ın von Aster hakkındaki ifadeleri șöyledir: "Üniversiteler büyük bir ailenin cüzüdürler. Bunun içindir ki bir üniversite Profesörü hangi memlekette bulunursa bulunsun üniversite içinde yabancı sayılmaz. Üniversitemiz de von Aster'i, aramıza girdiği günden itibaren aziz ve sevgili bir rüknü saymıș, ona güvenmiș ve onunla övünmüștü. Von Aster de üniversitemize karșı aynı alâkayı göstermiș, derin ilminden her fakültemizi, her çocuğumuzu istifade ettirmeğe çalıșmıs, kendisinden yardım İstediğimiz her sahada değerli yardımını esirgememiști. Von Aster'in çalıșmaları yalnız bağlı bulunduğu Edebiyat Fakültemize inhisar etmemiș, Hukuk ve İktisat Fakültelerimiz de bu muhterem hocanın nuru ile aydınlanmıștır. Bugün Edebiyat Fakültemizde olduğu gibi İktisat ve Hukuk Fakültelerinde de yetiștirdiği genç öğretim üyeleri onun yolunda yürümektedirler. (Onar, I949: I)

Așağıdaki notlarda von Aster, Descartes ve Newton'dan bașlayarak, bunların Leibniz ile ilișkilerini kurmakta; Mach'ın materyalizmi ile bunu sarsan kuantum fiziğini incelemektedir. Böylece Yeni Pozitivist ekole kadar Batı düșüncesinde önemli bir etki yapmıș filozofları ve düșünce sistemlerini eleștirel olarak anlatmaktadır. İște düșünürün ülkemize karșı 
duyduğu bu vefakârlığa saygının bir ifadesi olarak, I940’lı yıllarda İstanbul Üniversitesi Felsefe șubesinde vermiș olduğu seminerlerin notlarının bir bölümünü okuyuculara sunmayı düșündüm.

Bu notlar, I987 yılında buradaki bölümün de içinde olduğu daha geniș bir dosya halinde, değerli hocamız Prof. Dr. Șaban Teoman Duralı tarafindan bana ulaștı. Hocamız, bu notları okuyup yayınlamanın güzel bir hizmet olacağını düșünüyordu. Heyecanla, yüksek lisans tezimi bir yıl geciktirme bahasına bu notlarla uğrașmaya bașladım. İlkçağdan bașlayıp, çağımıza kadar bütün dosyaları daktilo ile yazdıktan sonra, dosyanın sahibi değerli sosyolog hocamız rahmetli Prof. Dr. Cahit Tanyol'a buradaki ders notlarının aslı ile bendeki transkripti karșılaștırmaları ve düzeltmeleri amacryla geri verdim.

Ancak ne yazık ki Tanyol hocamızın buna firsatları olmadı; dahası birlikte karșılaștıralım temennisiyle defalarca görüșmemize rağmen, yayınlamak üzere bu notları bir daha bulamadılar. Aradan uzun yıllar geçti; biz de çoğundan mahrum kalsak da, hiç olmazsa elimizde kalan bölümünden Türk okuyucularının mahrum kalmaması için bu kısmını yayınlamayı düșündüm. Bu yazılar derste tutulmuș notlar olduğu için zaman zaman tekrarlar ve cümle düşmeleri olması kaçınılmazdı. Bu tür cümleleri öncesi ve sonrasını göz önüne alarak düzenlemeye çalıștım. Ayrıca ders notlarını tutan kișilerin farklı olmasından ve 4o'lı yılların Türkçesi ile yazılmıș olmasından dolayı bazı terimler ve kavramlar bugün kullanılmamaktadır. Bu tür kelimelerin bazılarını cümle ahengini bozmamak için olduğu gibi bıraktım, bazılarının yanına (... ) içinde yeni kullanılan kelimeleri de verdim. Bazı kelimelerin yerine de günümüzde yaygın olarak kullanılanı kelimelerin kullanımı tercih edildi.

\section{Sonuç}

Yukarıda von Aster'in Türkiye'de İstanbul Üniversitesinin felsefe şubesinde, ömrünün sonlarına doğru bir sömestrde vermiș olduğu çağdaș felsefenin belli bașlı filozofları ve düșünce sistemleri hakkındaki dersi takdim edildi. Von Aster burada bize ders yöntemi olarak, güzel bir örnek sunmaktadır. Felsefe tarihinin sadece bir kronolojik bilgilerden ibaret olmadığı düșüncesini burada da sergilemektedir. Farklı dönemlerde yașamıș farklı filozoflar arasındaki düșünce bağlarını bir mekik gibi dokuyarak 
ve aynı dönemde yașamıș olan filozofların düșünceleri arasındaki ilișki ve farklılıkları da, adeta birbiriyle zincirleme halinde dizerek sunmaktadır.

Hayat felsefesinin ve yașantısının tutarlılığına da bir örnek olarak, düșünce tarihindeki birbirine en zıt iki düșünce sistemini kökünden reddetmeden, fakat kolaycılığı kaçıp hemen kabul etmeden, analiz etmekte ve eleștirmektedir. Böylece insan ruhunun ve bilincinin hürlüğ̈̈ne duyduğu saygıyı, aklın bağımsızlığı ile uzlaștırmaktadır.

Von Aster'in burada gösterdiği bir diğer örnek ise, bilim tarihinin en önemli olgusal ve tecrübi fikirleri ile felsefe tarihinin en soyut ve metafizik düșünceleri arasında kurmuș olduğu ahenktir. Böylece, mutlak hakikatin varlığını reddetmeden ancak onu küçük ve kısa bir düșünce ile sınırlandırmaksızın muhataplarına göstermesidir.

\section{Kaynaklar}

Akarsu, B. (1949). Öğrenci Gözü İle Ernst von Aster, İstanbul Üniversitesi Edebiyat Fakültesi Felsefe Arkivi, 2 (3), I9-2I.

Gökberk, M. (1949). Ernst von Aster'in Felsefedeki Yeri, Istanbul Üniversitesi Edebiyat Fakültesi Felsefe Arkivi, 2 (3), IO-I8.

Gökberk, M. (1982). Felsefe Taribi. İstanbul: Remzi Kitabevi.

Kranz, W. (1949). Ernst von Aster'in Șahsiyeti. İstanbul Üniversitesi Edebiyat Fakültesi Felsefe Arkivi, 2 (3), 7-9.

Onar, S. S. (1949). İstanbul Üniversitesi Rektörü Ord. Prof. Dr. Sıddik Sami Onar'in Ernst von Aster'in Vefatına Dair Söylevi, İstanbul Üniversitesi Edebiyat Fakültesi Felsefe Arkivi, 2 (3), I.

Tanyol, C. (1943-4). Ernst von Asterin Ders Notları Defteri. Osmanlica El Yazması Halinde. I. Sömestr.

Ülken, H. Z. (1949). Ernst von Aster ve Bilgi Teorisi, İstanbul Üniversitesi Edebiyat Fakültesi Felsefe Arkivi, 2 (3), 50-62.

Von Aster, E. (1942). Kant'ı n Ahlâkı, Üniversite Konferansları, I94I-I942 Y111, Üniversite Konferansları, İstanbul, Ayrı Basım, Sayfa: 25-34.

Von Aster, E. (1949). Modern Fizik ve Felsefe, İstanbul Üniversitesi Edebiyat Fakültesi Felsefe Arkivi, Cilt:2, Sayı:3, Sayfa: 98-ıo6.

Von Aster, E. (1994). Aster'in Yayınları, İstanbul Üniversitesi Edebiyat Fakültesi 
Felsefe Arkivi, Cilt:2. Sayı:3, Sayfa: 98-ıo6.

Von Aster, E. (1994). Bilgi Nazariyesi ve Mantık. (Çev. M. Gökberk). İstanbul: Sosyal Yayınlar.

Von Aster, E. (2005). Ernst von Asterin Ders Notları: İlkçă̆ ve Ortaçağ. (Sad. V. Okur). İstanbul: İm Yayıncılık.

Ek: Aster'in Çăgdaș Felsefe Ders Notları: (I9.II.I943)

Rene Descartes (1596-1650) ve Isaac Newton (1642-I727)

[...Ben geçen derste materyalizmi örnek olarak vermiștim. Benim için önemli olan, materyalizmin felsefi bakımdan tezahürlerini göstermektir. Bence bu felsefeye tatbik edilen hal tarzları aynen tekerrür etmez; zamanın ilmine tabidir. Ve tarihte daima bir septisizm, bir pozitivizm ve bir idealizm mevcuttur. Fakat devrinin ilmine göre șekil değiștirir. Aynı șekilde, Yeniçağ felsefesinde de bunun muhtelif tezahürlerini göreceğiz. Demek ki felsefede, bir ebedi olan; bir de zamana göre değișen taraf olmak üzere iki taraf vardır.

Descartes fiziği ile Newton fiziği arasında da "böyle bir" görüș farkı vardır. Descartes, mekânı akıșkan bir madde olarak kabul eder. Bu hareket suya batırılan bir çubuğun çevrilmesi suretiyle hâsıl olan dalgalar tarzında bir harekettir. Bu dalgalarda bir kamıș parçası olsa, o da dalgalarla beraber dönecektir.

İște esir dediğimiz bu akıșkan madde içinde gezegenler hareket ediyor. Newton'a göre mekân boștur ve içinde cisimler vardır. Bu cisimler, sahip oldukları kuvvetler sayesinde birbirlerini çeker veya iter. Newton iki gezegenin birbirlerine tesirini de hesap ediyor. Bu telakkinin Descartes'in telakkisinin yerine geçmesi uzun bir zamana ihtiyaç göstermiștir. Newton'un telakkisi gezegenlerinin hareketlerini önceden tayin etmeyi ve hangi yörüngeden geçeceğini anlamayı mümkün kılıyordu.

Demek ki Newton'un felsefesi yıldızların uzay içerisindeki hareketlerini önceden tayin etmeye imkân veriyordu. Diğer bir faydası da düșme ile ilgilidir. Biliyorsunuz ki dayanağı olmayan bir cisim yere düșer; ancak bu cisim rastgele düșmez. Bunun bir sürati vardır ki o da artar veya eksilir.

Newton'un dayanağı olmayan bir cisme tatbik ettiği doktrin, aynı yöndeki yıldızların aynı kanuna tabi olduğunu da ispat etti. Güneș’in etra- 
findaki gezegenlerin de her birisi aynı kanuna tabidir ve bu telakki ebedidir (genel geçerdir). İçinde bu sayede mekanik astronomi geliști. Descartes'ın fiziği de bir uzay mekaniği kurmak istiyordu, fakat bu mümkün olamiyordu.

Bu suretle mekanik, fizik ve astronominin temel ilmi oluyor. Astronomiye diğer bir ilim katılıyor. O da optiktir. Ișık yansıdığında optikte renkler bütününü teșkil eder. Newton'a göre 1șık küçük zerrelerin hareketinden meydana gelir. Böylece Newton bu esaslardan hareket ederek, 1ş1k mekaniğini ve renk mekaniğini tesis ediyor. Böylece köklü bir fizik tesis etmiș oluyor.

Geçen ders La Mettrie (Julien Offray de La Mettrie (I709-I75I)'den "L'Homme Machine” eseri dolayısıyla bahsettim. Ona göre bütün mekânın ana esası makinedir. Bu kanun insanlara da tatbik ediliyordu. Bir makinede karakteristik olan nedir? Makine, mekanik kanunlara göre çalıșır. $\mathrm{O}$ halde bu felsefeye göre kâinat dahi bir makinedir. Mekanik kanunlar bütün hadiselere hâkimdirler. Böyle bir felsefede Allah'a hiçbir yer ayrılmamıștır. Kâinata hâkim bir kuvvetin olmadığı düșüncesi çıkıyor ki bu materyalistlerin noktayı nazarıdır.

Bunun yanında bir de Deizm telakkisi vardır. Bu telakki, kâinata hâkim olan mekanik kanunların değil, yaratıcı bir kuvvetin olduğunu kabul eder. Newton ise bu istikametlerden hiçbirine ait değildir. Bizzat o dindar bir zat idi. Onun için Allah'ın mevcudiyeti șüphe götürmez ve mucizeler de mümkündür. Fakat o aynı zamanda mekanist telakkinin kuvvetlenmesine de sebep olmuștur. Hususi olarak șu sual meydana çık1yor: İnsandaki hürriyet, yani irade nasıl mümkündür? La Mettrie irade hürriyetini kabul etmez, zira insan makinedir. İnsanın da makine gibi irade hürriyeti yoktur.

\section{Immanuel Kant (1724-I804): (6.I2.1943)}

Kant, I8. ve I9.'u asır içerisinde bulunduğu için şimdi onunla meşgul olacağız. Kant, Newton'u așıyor ve bir kozmogoni tesis ediyor. Kozmogoni kâinatın menșei hakkında bir fikir demektir. Diğer bir tabirle gezegenlere ait bir fikirdir. Kant'a göre bizim güneș sistemimiz teșekkülden evvel bir ses bulutu idi. Kant'ın kâinatın menșei hakkında koyduğu fikir eğer doğru olarak kabul edilirse; O Newton fiziğini kabul eden bir müte- 
fekkirdir. Yani tabiata mekanik kanunların hâkim olduğu aynen kabul ediliyordu. Kant'ın bu mühim fikri felsefenin bașına konmuștur. Bu fikir șudur: Bir cisim ancak iki tarzda telakki edilebilir; bize göründüğü gibi veya (bizatihi) mevcut olduğu gibi.

Kant'a göre duyu organlarımıza tesir eden obje, bizatihi objenin kendisi değildir. Tabiat unsurları yalnız objenin bu görünüș tarafiyla bilinirler. Tabiattaki șeyler, zaman ve mekân dâhilinde görülürler. Zaman ve mekân görünüșlerin șeklinden bașka bir șey değildir. Kâinatın bu yüzünde, yani görünüșlerde illiyet kanunları hâkimdir. Yani nedensellik kanunları ve zorunluluk hâkimdir. Hâlbuki bizatihi șeyler âleminde ne zorluluk vardır ne de nedensellik. Bizim idrak ettiğimiz dünya ancak zaman ve mekân dâhilinde olan dünyadır.

Hâlbuki zaman ve mekân dâhilinde tasavvur edilmiș her șey, illiyet kanunlarına tabidir. Eğer insan yalnız bundan ibaret olsaydı, insan da tabiatın bu kanunundan uzak kalamayacaktır. Fakat insanda diğer bir âlem vardır ki; bu zamandan ve mekândan uzaktır. Yani, insan iki âlemi kușatmaktadir.

I- Mekanik dünya (zorunluluk sahası)

2- İradi dünya (özgürlük sahası)

O halde Kant insana irade sahasını ayırıyor. Çünkü insanda böyle bir varlığı kabul zaruridir. Kant tabiat için mekanik telakkiyi kabul ediyor. İnsan, ona göre tabiattan ayrı bir karakter arz eder. İnsana hususi bir mevki ve irade hürriyeti veriyor.

Kant'ı bu telakkiye ahlaki bir șuur sevk etmiștir. Eğer tabiatta mekanik bir zorunluluk olsaydı, ne iyi ne de kötü mefhumu (kavramı) mevcut olamazdı. Fakat bizim șuurumuzun kararına göre bunlar dünyada vardır. İnsan kendisine bir vazife tevcih eder. Böyle bir vazife ifası hürriyete bağlıdır. Kant, tabiat hakkında düșündüğü zaman, gerekirci bir telakkiye sahiptir. İnsan mevzubahis olunca da fikri değișir. Demek ki Kant iki türlü tabiat kabul ediyor:

a) Nedenselliğin geçerli olduğu mekanik bir tabiat

b) Ahlaki șuurun kabul edildiği iradi bir tabiat

O halde Kant, I8. asırdaki determinist anlayıșa sahip değildir. Kant determinizmi sadece tabiat kanunları söz konusu olduğunda kabul ediyor. 


\section{Franz Clemens Brentano (1838-1917): (3.3.1944)}

Şimdi esas meseleye, yani hakikat problemine dönüyoruz. Șüpheden arınmıș olan hakikatin bilgisini yahut hakikat olarak bilgiyi nasıl temin edebiliriz? sorusuna dönelim.

Brentano, buna șu șekilde cevap veriyor: "Bazı nitelikler vardır ki, bunlardaki hakiki ve apaçık olan yanı bilavasıta (aracısız) olarak görürüz." Yahut aynı șeyi kastederek, "apaçı önermeler mevcuttur." der. O halde hakikatin tecrübesi, apaçık önermelerin tecrübesi ile aynı olur. İki türlü apaçık önerme vardır. Birincisi, tecrübe denilen öğrenmeyle elde ettiğimiz apaçık önermeler. Şimdi önümde beyaz bir renk gördüğümden ve bazı sesler ișittiğimden șüphe edemem. Bu șüphe edilmeyen șeyler bilavasıta (arac1sız) apaçıktırlar. Tecrübemin ve idrakimin temin ettiği her șey bilavasıta bedihidir.

Burada Descartes ile aynı șeyi kast ediyor. Descartes'a göre de dâhili idrake verilen șeyler apaçıktırlar. Bundan bașka rasyonel hakikatler vardır ki, bunlar da Descartes'ta șüpheden uzaktır. Mesela, bir objenin aynı zamanda var olması veya olmaması meselesi gibi.

Brentano'ya göre diğer bir apaçık önerme ise şudur: Mevcut her șeyin mevcudiyetini, mutlaka bir sebebe dayandırırız. Bunların hakikat olmalarının zorunlu olduğunu görürüz. Bunlar kesin delillerdir ki, akıl bunları tasdik eder, fakat asla inkâr etmez. Mesela, bir obje aynı zamanda hem var hem yok olamaz. Birini herhangi bir șekilde ispat edemeyiz. Hatta bir șekilden bașka türlü olmayacağını bedihi bir șekilde biliriz. O halde hem tecrübi hem aklî hakikatler vardır ki, bu iki tarzdaki hakikate bedihi olan hakikatlerdir. Bu hakikatleri temellendirmeye çalıșmak manasızdır. Çünkü bunları temellendirmek için kullanacağımız kaziyeler (önerme) yine buna dayanacaktır.

O halde bunlar tahkik önermelerine ihtiyaç göstermezler. Mühim olan șey bir tarafta tecrübi diğer yanda akli hakikatlerin mevcudiyetidir. Demek ki bilgi ne yalnız tecrübeye, ne yalnız akla istinat eder. Bilgi, her ikisine de istinat eder. Her iki bilgi çeșidi bizim bütün bilgilerimizin esasını teșkil ediyor. O halde, sadece bir rasyonalizm, bir empirizm haksızdır. Ancak ikisi birleșirse aklî olabilirler.

Brentano'nun ortaya koyduğu ikinci önemli önerme de șudur. Bütün 
bilgilerimiz gerçek olan șeye yöneliktir. Her bilgi, var olan bir objeler sahasını șart koșar. Bundan bașka var olan șeylerin mevcudiyeti de aynı zamanda bedihi (apaçı) bir kaziye (önerme) dir. Evvel-emirde bedihi olan benim kendi mevcudiyetimdir. Salt tecrübenin objeleri olan gerçek olanların mevcudiyeti de yine böyle gerçek bir kaziyedir.

Bunlardan başka salt mantık ve riyaziyenin önermeleri de apaçıktırlar. Bunlar da var olan șeye yöneliktir. Brentano'ya göre salt mantık önermeleri, tesirleri menfi olan önermelerdir. Mesela, misal olarak çelișkili önermeleri alalım. Bu önermelerin ifadesi: Aynı zamanda mevcut olan ve olmayan objeler yoktu. Demek ki birbirleriyle çelișkili önermelerin de hakiki ifadesidir. Bu varlı̆̆ı çelișkili olarak telakki eden bir önermedir. Belirli șeylerin varlığını reddediyor. Mesela: "Bir üçgenin iç açılarının toplamı I80 derecedir" demek böyle bir önermedir. Yani hiçbir cisim, hiçbir üçgen mevcut değildir ki, bunun haricinde olsun. $\mathrm{O}$ halde bu önermede bütün bilgi gerçek olan bilgiye yöneliktir.

İște bu gibi önermeler ya olumlu veya olumsuz olurlar. Bundan bașka apaçık olan bir șey mesela, șu anda bu kitabı idrak etmem de bir apaçıklıktır. Burada apaçık olmayan taraf, bu kitabın mevcudiyetidir. Çünkü bu mevcudiyet bir bașkasına göre yok da olabilir. Çünkü benim tarafımdan idrak edilen hariç dünya, bir bașkası tarafından reddedilebilir. Bu düșünülebilir bir haldir. Fakat böyle bir varsayım yanlıs, değildir. Fakat çok uzak bir ihtimalle bunun doğru olması mümkündür.

Demek ki, aynı zamanda ihtimaliyetin de bir apaçıklığı vardır. Mesela, idrak ettiğim bir objenin mevcudiyeti hakkında söyleyeceğimiz söz, onun ihtimaliyetinin biriyle olmasına dayanır. Benim idrakimin muhtevasını teșkil eden akıșkan dünyanın kesin apaçık olması doğru demektir. Çünkü apaçıklık, bununla yüksek bir ihtimaliyeti ihtiva eder. İlim onun için tamamıyla apaçık olan önermelerle çalıșmaz. Apaçıklığı muhtemel olan önermelerle çalıșır. O halde Brentano'nun fikirlerini șu ifadelerde toplayabiliriz: "Bütün bilgilerimiz var olan obje sabasındadır."

Kesin bir surette apaçık olan önermeler mevcuttur. Bu önermeler kısmen rasyonel, kısmen empiriktirler. $\mathrm{Bu}$ apaçık surette muhtemel önermeler mevcuttur. Ayrıca en yüksek bir apaçıklık ihtiva eden, bedihi önermelere șu önerme de dâhildir: "Bu dünyayı yaratan makul bir varlık olması lazımdır. Yani Allab'ın mevcudiyeti de bedibidir." Yüksek bir açıklık 
ihtiva eden önermeler gibi, bir hisse dayanmayan bir ruhun mevcudiyeti de kesindir. Çünkü insan vücudu etrafındaki șeyleri idrak eder. Böyle bir idrakin husule gelebilmesi için bir göze ihtiyaç vardır. Burada ișittiren ve tesir eden, aslında ruhtur. Görüyorsunuz ki, aynı zamanda dini iddiaları istinat ettirecek bir metafizik de gerekmektedir.

Bu nakillerde görüyorsunuz ki; Brentano, Kant'ın temel önermesinin tam tersini iddia ediyor. Çünkü Kant, Allah'ın ve ruhun mevcudiyetini ispat edecek bir metafiziği reddederken, Brentano bunları kabul eder. Hatta Brentano'ya göre, böyle bir metafizik, sadece apaçık hakikatleri ihtiva etmez; aynı zamanda, yüksek bir ihtimaliyet tașıyan bedaheti de ihtiva eder. Kant harici dünyanın mevcudiyetinin ispat edilemeyeceğini; Brentano bunun yüksek bir ihtimaliyet tașıdığını söyler.

Kant'a göre bilgi demek, ihsas ve idrak duyularımızı ișletmek ve birbirine raptettirmek demektir. Brentano'ya göre ise bilgi, harici olan gerçek suretlere var olan șeyi tatbik eder. Bunlardan kazanılan șeylerin bir kısmı apaçıktırlar bir kısmı da ihtimal dâhilinde apaçıktırlar. Diğer önemli olan bir nokta ise Brentano, akıl duyusunun bilgilenmesi konusunda ise Locke ile farklı düșünür.

Locke ve diğer empiristler, metafiziksiz bir ruhaniyat ve felsefeyi göz önünde bulundururlar. Locke'un en önemli sorusu șu idi: "Bizim şuurumuz bangi unsurların terkibidir? O balde șuur neden teșekkül eder?" Șuur ona göre, en basit ve en son olan duyuların öğelerinden teșekkül eder. Șu anki șuurum, șimdi gördügüm renklerden ve ișittiğim șeylerden teșekkül eder. Demek ki șuuru tahlil ettiğimiz zaman elde edeceğimiz șeyler; his, ihsas ve idrak muhtevalarıdır. Çünkü șuur bunlardan müteșekkildir.

Oysa Brentano bașka bir mefhumdan hareket eder. Bu mefhuma biz Ortaçağda rastlamaktayız. Locke'un iddia ettiği șeyler, Brentano'ya göre benim șuurumun müteveccih olduğu (yöneldiği) objelerdir. Benim gördügüm renk(in), șuurumun bir objesi ile birlikte renk olabilmesi için, benim onu görebilmem lazımdır. Rengin bașka bir görünümü vardır. İște bu görünüm aklidir. Herhangi bir șeyin mevcudiyeti ancak akılla mümkündür.

Demek ki ben bir uzvumla (kulak) bir ses ișittiğimde, bu ses maziye karıștığı zaman bile, benim diğer bir aktım (hatırlama aktı) vasıtasıyla 
bunu hatırlayabilirim. Ses ișitme aktının objesi olduğu gibi, mahlûkatın da objesi olabilir. Ben görüyorum, ișitiyorum yahut sesleniyorum. Bunlar aktlardır. Böyle objelere yöneliktirler. Bu aktların merkez noktası olan șeylere de ben ide derim. Çünkü ben görüyorum, ișitiyorum, hüküm veriyorum. Ben yalnız ișittiğim sesi değil, aynı zamanda bir șeyi ișittiğimi de biliyorum.

Bizim șuur dediğimiz șey, bizim hasselerimizin bir sentezi (terkibi) idi. Evvela șuuruna sahip olduğum bir obje, bir insan, bir ev vs. bunlardan sonra ikinci derecede benim faaliyetlerim gelmektedir. Mesela bir șeyi ișitme ve görme faaliyeti... Bunun gibi objelere yönelik faaliyetler silsilesinin hepsini kușatır $O$ halde șuur, Locke'un zannettiği gibi sadece idrak, ihsas, his unsurlarından ibaret değildir. Șuurun muhtevasını bir ideler silsilesi teșkil eder.

Herhangi bir șeyin varlığı iki suretle vakidir: Birincisi o șeyin kendisi ve diğeri de (benim) onu hatırlamamdır. Demek șuur böyle bir hasseler silsilesinden, yani idelerle münasebetlerden teșekkül eder. Biz bu sayede hariçteki objelerin șuurlarına sahip oluyoruz. Brentano bu suretle ortaçağdaki ide fikrini tekrar canlandırıyor.

Ortaçağdan Yeniçağ felsefesine kadar devam eden bu kavram (ideler fikri), Yeniçağda yeniden ortaya çıktı. Locke'a göre, șimdiye kadar sayd1ğım idelerden başka bir de sevgi ve nefret ideleri vardır. Nasıl ki apaçık varlık hakkında bir șuur varsa; yalan ve nefret hakkında da yine apaçık bir şuur mevcuttur. Mesela ben herhangi bir șeyi sevdiğim olarak sevdiğimin şuuruna malikim. Biz bir objeyi haklı olarak seviyoruz. Biz diyebiliriz ki onu iyi bir șey olarak seviyoruz. O halde apaçık olan kıymet hükümleri mevcuttur.

$\mathrm{Bu}$ apaçık kıymet hükümleri mevcuttur ve bu apaçık değer yargıları üstüne etik temellendirilir. Etik neyin iyi ve neyin kötü olduğunu bize öğretir. Nasıl ki akıl bilgisi, doğru ve yanlıșı öğretiyorsa; aynı șekilde yalan söylemenin kötü bir șey olduğunu etik bilgimiz bize söyler. Demek ki biz moral sayesinde bir objenin sevgi değeri ve nefret değeri șuuruna malikiz. Bunları ispata ihtiyaç yoktur. Brentano'ya göre bütün insanlar hangi millete ait olurlarsa olsunlar, kıymet hükümleri yani iyi ve kötü hakkındaki fikirleri birbirine uyar. 
Filhakika, ahlakta da hatalar mevcut olabilir. Bu tür hatalar bilgide de mevcuttur. Yalnız insanların birbirleriyle ortak olan apaçık değer yargıları, farklı hükümlerden daha çoktur. Sual: ahlakın etik tarafı var mıdır? Kıymetten (değer) hareket eden bir etik, hakikatler etiğine yaklașır. Buna göre, ahlak sahasının etik sahasından ayırt edilmesi çok güçleșir. Biz bu etiği ahlaki olan etikle karșılaștıralım: Mesela Max Scheler'in etiği kıymete dayanır. Bu etiğin karșısında Kant'ın ve Yeni Kantçıların etiği konabilir.

Kant, ahlakında impératif mefhumundan hareket eder. Kant'a göre insanlar ahlak ilkelerine göre hareket ederler. Ben bunu yapabilirim veya șunu yapamam. Demek ki Kant'a göre etiğin sahası, değerler sahasıdır. Fakat etik ancak vazifeye (ödev) yahut emirlere (buyruk) istinat edebilir. Çünkü etiğin hareket noktası daima emirlerdir. Bu gibi noktalar etiğin hareket noktasını teșkil eder. Bir insanın mesela yalan söylemesi, o insan için kötü bir șey görülüyor. Çünkü ahlak kanunu; "sen bunu yapamayacak$s ı n "$ der. Ama bu eylem bir bașkası tarafından güzel görülebilir. Kant'a göre böyle bir insan hayatını, ahlaki açıdan değil de estetik açıdan ele alan ve tetkik eden bir insandir.

Kant'a göre böyle bir insan, aslında etik ile estetiği birbirine karıștırıyordur; yani iyiyle güzeli. Kant'a göre filhakika güzelliğin de ahlakta bir yeri vardır. Fakat bunun yeri ikinci derecedendir. İnsanlarda ahlaki bir his vardır. Bunun nedeni merhamet hissidir. Ahlaki kaidelere göre hareket eden bir insanı iyi sanıyorum. Bu his yani ancak ahlaki faydanın bir neticesi olabilir. Bu hareketin dayandığı nokta da itaattir. Demek ki böyle bir irade ile, emirlere itaat ettiğimi gösteriyorum. İște bu anlatılanlardan, Kant'ta ahlakın hareket noktasıyla, Brentano'nun hareket noktasının bașka olduğunu görüyorsunuz.

Kant'ın tabii olarak İngiliz ahlakına yaptı̆ğ itiraz șudur: "Bunlar ablakı estetikleștiriyorlar" diyor. Hâlbuki mesela Schelling'e göre biz emirlere șunun için itaat ediyoruz: "Biz bu emirlerin kıymetinin bilincine sahibiz; fakat biz aynı zamanda, bir șeyin sınırlı olduğunun bilincine de sahibiz. Bir șeyi gerçekleștirmeye çalıșıyoruz. O halde evvela, onun kıymeti hakkında bilgi, sonra emirler gelir." Oysa Kant tam bunun tersini söyler: "İlk olarak emirler, sonra buna taalluk eden bilgi gelir" der.

Bunlar (Kant ve Schelling) arasındaki düșünce farkını anlamak kolay- 
dır. Fakat burada metotlara karșı nasıl bir tavır almak gerekir? Kant'ın kendisi böyle emirler altında yașayan bir insan olduğundan, böyle bir etiği kabul etmiștir.

Bunu anlamak için bir örnek olarak mesela eski filozoflardan Aristo ve Eflatun'u ele alalım. Eflatun'a göre her șey (bütün objeler) idelere göredirler. Objeleri tanımak demek onların idelerini tanımak demektir. İște bu nedenle İlkçağ etiği esası itibarıyla bir kıymetler etiğidir. Diğer yandan iyi olan bir șeyin güzel olduğunu da apaçık bir gerçek olarak kabul ederler. Yunan felsefesinde böyle bir temayül vardır. Yani iyi ve güzeli özdeșleștirmek temayülü vardır. Buna göre, "etik ve estetiği özdeșleștirmek tabii midir" sorusuna cevap vermek çok güçtür.

\section{Edmund Husserl (1859-1938)}

Brentano'nun tesiri ile ilgili olarak, Fenomenolojinin kurucusu olan Husserl'den bahsedeceğiz. Husserl, Brentano'nun talebesidir. Fakat kendisi mühim bir noktada Brentano'dan ayrıldı. Husserl üzerinde Brentano'nun en önemli etkisi fenomenoloji hakkındadır. İkinci nokta ise bedahet (açıklık) mefhumudur. Fenomenolojik felsefenin ilk kitabı "Mantık Araștırmalar" adındaki bir eserdir. I9oo'de ortaya çıktı. Bu eserde Husserl, psikolojizm ile mücadele eder ve mantığın bağımsızlığı için çalıșır. Husserl'in eserinin esaslarını; "Mantı̆̆ın temeli nedir? Ve Aristo'nun önermeleri ne sekil esasları ibtiva eder?" gibi sorular olușturmaktadır.

Mantığın bu tür konuları aslında düșünmenin kanunları değildir. Düşünmenin kanunları fenomonolojinin kanunları olabilir. Çünkü mesela çelișki kanunu, bizim gelecekte nasıl düșünmemiz lazım geldiğini göstermez. Bilakis bunun ifadesi șudur: Çelișkili önermeler, hakikat olamazlar. $\mathrm{Bu}$ önermenin geçerliliği, insanın șöyle veya böyle düșüncelerine tabi değildir. Demek ki bunun geçerliliği, insanlara tabi değildir. Ĕ̆ger bu insan düșünmesinin kanunları olabilirse șöyle düșünebilirdik: Bașka mahlûklar olsaydı ki bunlar bașka kanunlara göre düșünebilirlerdi.

Psikolojinin meşgul olduğu saha, insanlar ve onlara ait olaylardır. Mantık ise, kaziyeler ve kanunlarla meșgul olur. Mantık yalnız ruhi șeylerle değil, bașka șeylerle de uğrașır. En yakın bulunduğu șey de riyazî (matematik) bilgidir. Zira riyaziyenin bu düșünce kanunları, bizzat onlara tabi değildir. 2x2=4 eder önermesi insanların mevcudiyetine tabi değildir. İn- 
sanlar bunu düșünebilsin diye, düşünmesinin geçerli olması için var olan bir önermedir.

Bu riyazî önerme nereden çıkar. Çünkü bir sayı olan 2 ve 2'den neș'et eder. Bunlar objelerdir ve mantığın bu objeleri materyal objeler değil, ideal objelerdir. İki insan tasavvur edelim, ikisi de bu objeleri düșünüyor. $(2 \times 2=4) \ldots$ Buradaki sayılar iki türlüdür. İki insanın șuurunda da cereyan eden sayı bașkadır. Fakat objeleri birdir. Yani hedefledikleri șey aynı șeydir. Bu obje materyal bir obje değil, idealdir. Çünkü yalnız materyal objeler değil aynı zamanda ideal objeler de mevcuttur. Çünkü ideal objeler de düșünülebilirler. Biz bu objeleri de düșünebilir, hatta diğer objelerden ayırt edebiliriz. Hatta tahkiki hasselerimizle (duyularımız) bunları idrak edebiliriz. Çünkü ancak cisimlere dokunabilir ve görebilirim.

İdeal objeleri iki açıdan düșünebilirim. Bu objeleri düșünebilirim demek bunları bir veri haline getirebilirim demektir. Ben bunları fenomen haline getirebilirim; ancak duyu organlarına dayandırarak değil. Bütün fenomenleri, görülecek, ișitilecek șeyler olarak kabul etmek doğru değildir. Fenomen sahası bundan daha geniștir. Husserl'e göre neyin fenomen olabileceği, neyin olamayacağı ciddi bir șekilde araștırılmaktadır. Bu ilmin adı fenomenolojidir. Husserl'e göre o zamana kadar böyle bir fenomonoloji mevcut değildir. Bunun tersi șuydu: Görülebilen, ișitilebilen șeylerin obje olduğuna kani idiler. Biz gelecek derste fenomonoloji deyiminin neye dayandı̆̆ını göreceğiz.

Biz hali hazırdaki fenomonolojinin esasını izah edeceğiz. Bu akımın temsilcisi Husserl'dir. Bu zat mantıki konuların müstakil olduğundan ve psikolojik kanunlara tabi olmadı̆̆ından bahseden bir eser neșretti. Eserin adı "Bilginin Esasına Dair Araștırmalar”dır. Bu zat fenomonoloji kelimesini kendi araștırmalarını karakterize etmek için kullanır. Daha sonraları ise bu istikamette çalıșan bütün filozoflar aynı kelimeyi kullandılar.

Fenomonoloji nedir? Fenomenlerin ilmi demektir. Fenomen (görünüş) kelimesi burada çok geniş manada kullanılmıștır. Șuurun objesi ve șuur hakkında bir tefekkürdür. Hareket noktası umumiyetle, "șuur ne demektir?" meselesidir. Fenomonolojinin buna verdiği cevap, önceki filozoflardan çok bașkadır. Çünkü șuurun ne olduğu meselesini, önceden Locke, Hume ve Berkeley de sormușlardı. 
Hume ve Locke'a göre șuur ne demektir? Bu filozoflara göre șuur birçok muhtevadan teșekkül eder. Demek ki șuur, birbirlerini takip eden șuur muhtevalarından teșekkül eder. Hume'a göre șuur muhtevaları üç șeyi içermektedir:

I- Süje, bu kendi hakkında bir șuura varmaktır.

2- Obje, bunun hakkında șuur bir șeye sahiptir.

3- Akıșkan bir akt mefhumu, șuura aittir ki süje ile obje arasında bir münasebet kurar.

Bu aktlar muhtelif olabilir. İdrak, görme aktı, duyma aktı gibi... Bütün bu aktlarda șuur bir obje ile münasebettedir. Bu aktlar hakkında șuurun bir bilgisi vardır; yani șuur bir șuura sahiptir. Ben elindeki kitabı görüyorum. Aynı zamanda bu kitabı görebilme șuuruna da sahibimdir. Demek ki, șuur sadece muhtevalarının bir toplamından ibaret değildir; bir akt sırasında teșekkül eder ki bu akt sisteminden șuur haberdardır. Fenomonoloji evvelemirde tasviri (betimletici) bir ilimdir. Yani her șeyi olduğu gibi tasvir eder ki bunun manası da, șuurda görülen objeler sahasıdır. Șimdi bu felsefeyi diğer ilimlerle mütalaa edelim.

Diğer ilimler objelerle meșgul olurlar. Diğer bir tabirle, diğer ilimler, objelerle alakalıdır. Ancak, "biz objeler hakkında herhangi bir bilince sahip miyiz?" sorusunu sormazlar. Mesela fizik ilmi, fiziği, tabiatı incelerse de; "bunlar hakkında herhangi bir bilince sahip miyiz, değil miyiz?" sorusunu sormaz. Diğer ilimler de öyledir. Mesela: hukuk kendi sahası olan Hak kavramını incelerken, bunu obje olarak düșünür. Bunlarla ilgili olan șuurla ilgilenmez.

Fenomenolojinin iki kısma ayrıldığını görmekteyiz. Birincisi objeleri tespit etmekle meşgul olur. İkincisi ise bu objelerle ilgili olan bilinç meselesiyle ilgilenir. Demek ki fenomenoloji evvelmirde bir ontolojidir. Ontoloji tarihinde, objeler hakkında birçok teoriler ortaya atılmıștır. Mesela materyalizm bunlardan biridir. Diğer bir teori de psikolojizmdir. Bu filozoflardan psikolojistlerin iddialarına göre objelerin esasını, bilinç olayı olușturur. Bunlar iddialarında daha da ileri giderek, objeyi bilinç alanına indirgediler. Mesela sayılar maddi objeler midir? Io sayısı ruhi bir olgu mudur yoksa bir duyum muhtevası mıdır? Șüphesiz ikisi de değildir; IO sayısı bir idedir. 
Șimdi hepimiz ıo sayısını düșünelim. Bu sayı, sayllar dizisini göz önünde tutan herkes tarafından düșünülebilir. Bu obje ne maddi ne de psikolojiktir; ıo sayısı bir "ide" dir. Çünkü bütün objeler maddi yahut manevi olmayabilirler; ama ideal objeler kesinlikle vardır. Bütün insanların ölümlü olduğunu düșünelim. Hep birlikte düşünelim. Acaba hepimiz aynı șeyi mi yoksa farklı objeleri mi düşünüyoruz? Șüphesiz hepimizin düșündügü șey aynıdır. Düșündügümüz obje belirli bir objedir. Obje olarak bu mana ne maddi ne de ruhidir.

İște Husserl ve öğrencileri bütün objelere bir eșya (obje) anlamı veriyorlar. Ancak buradaki eșya sadece maddi olmayıp, bir mana da taşımaktadır. Görüyoruz ki burada obje kavramı maddi sahadan daha derin bir sahayı ihtiva etmektedir. "ıо" sayısının ve "bütün insanlar ölümlüdür" önermesinin mevcudiyeti bir maddenin mevcudiyeti gibi vakidir. Fakat mevcudiyetleri aynı olmayıp farklıdır. Çünkü "ıo" sayısının varlık tarzı başka türdendir. "Bütün insanlar ölümlüdür" önermesinin varlığı da bașka türden bir varlıktır. Demek ki yalnız objeler değil, objelerin varlık tarzları da mevcuttur. $O$ halde fenomenolojinin vazifelerinden biri de "ne tür objeler vardır?" meselesini kaydetmektir. Geniș manasıyla buna biz ontolojik araștırma diyoruz. Çünkü objelerin varlık türlerini araștırır.

Antik felsefede Aristo ve Platon ontolojiyi felsefenin temeli yapmak istediler. Fakat ontoloji zamanla sair sahaların da araștırılmasına yöneldi. Yahut da yalnız bir türlü varlığı kabul ediyor. Hâlbuki varlığın muhtelif șekilleri vardır. Bu varlığın ve sairlerinin birbirleriyle alakaları vardır. Misal: sayılar sahası, maddi objeler sahasına ilgisiz değildir. Deminde söylediğimiz gibi adetler sahasındaki varlık ile maddi saha arasında münasebet vardır. Çünkü sayıları diğer sahalara tatbik ediyoruz. Maddi ve ruhi olanı sayıyoruz. Demek ki soru șöyle bir șekil alıyor: "Ne șekil obje sabaları vardir? Yani hangi cins varlık nevileri vardır?"

Fenomonolojiye göre, yeni felsefe ontolojik soruları ihmal etmiștir. Eğer böyle bir ontoloji mevcutsa, bu ontoloji inceleme konusu olarak neye sahiptir. Buna binaen; bu metot tasavvuru olan her șeyi tasvir suretiyle anlatır. Eșyada soyut olan șeylere bakan metottur. (Ontolojiden farklı bir olan) Fenomonolojinin metodu ise, șuurumuzun tesadüf ettiği șeyleri olduğu gibi tasvirdir.

Burada nazarı dikkati çeken bir șey daha vardır. Biz bu neticeye ne 
suretle vardık? Diğer bilgiler șuurda bir süje ve akt olduğu iddiasına nasıl vardı? Biz șuuru analiz suretiyle bir neticeye vardık. Șuuru tahlil etmek demek, belirli bir akt'ı tahlil demektir. Eğer biz șuuru incelersek, tekil bir akttan hareket ederiz. Fakat bu tekil akt bizim için ancak bir örnek olabilir. Bu metottan hareket ederek, genel bir sonuca varabiliriz. O halde, fenomenoloji biliminin istediği șey, bu münferit akt değil, șuurun mahiyetidir.

Burada mühim bir noktaya geldik. Bütün bilgi hadisesinde iki șekil görürüz. Önce gözümü açtığımda bir objeyi görürüm. Sonra bu objeyi tetkik etmeye başlıyorum. Aynı zamanda bu objeyi biz genel olanın bir dalı olarak kabul edebiliriz. Önümdeki kırmızı rengi, buradaki ferdi renk olarak kabul edelim. İkinci olarak șöyle de kabul edebiliriz. Bu kırmızı, mevcut kırmızı rengin bir misalidir. Daha genel söylersek, bu kırmızııı renk kavramının bir örneği olarak telakki ederiz. Böylece evvela kırmızı rengi, genel olarak da renk kavramını tetkik ederiz.

Böylece biz tecrit (soyutlama) ve tamime (genelleștirme) aktlarına dayanırız. Bu aktlar bize umumi objeler temin eder. İlk önce önümüzdeki kırmızı, sonra, genel olarak kırmızı; en sonunda da genel olarak renk kavramına varırım. Demek öyle aktlar vardır ki, biz bunlar sayesinde objelerin șuuruna varabiliriz.

Aynı șekilde bir üçgeni ele alalım: Tahtada çizdiğimi önce tekil bir șey olarak kabul edelim. Fakat ben bunu genel olan üçgenin bir örneği olarak kabul ederim. Hatta buradan hareket ederek, bir müsellesin (üçgen) neden ibaret olduğu kavramına yükselirim. O halde her defasında yeni bir akttan hareket ederek, șekil kavramına kadar yükselebilirim. Ferdi objeler mevcut olduğu gibi umumi objelerde mevcuttur. Aslında bu umumi objeler görülmezler; fakat zihinde düșünülürler. Fakat bu görüș duyuma dayanan bir idrak (algi) değildir. Duyuma dayanana örnek olan, hareket noktası teșkil eden șeydir.

Şimdi Husserl'i bırakalım, Locke ve Hume arasındaki farka dönelim. Bunların ortak noktası, yalnızca hasseye (duyuma) dayanan mutayı (veri) kabul etmeleridir. Yani bunlar, mutayı hasseye (duyum) istinat ettiren șeyleri vakıa olarak alırlar. Husserl ise, "tek olanı değil, aynı zamanda umumi mabiyeti de görebilmeliyiz" diyor. 
Ona göre, objeye taalluk eden iki tür bilgi vardır: Öncelikle, objeyi ona verdiğim bir işaret, bir isim sayesinde tanıyorum. Benim bir cümleyi anlamam demek, onun teșkil ettiği kelimeleri anlamam demektir. Aynı zamanda bu kelimelerle tasarruf edilen manayı bir görüș haline getirebilirim. Mesela: herhangi bir insana ait ismi hatırlayarak ait olduğu șahs1 hafızamda canlandırıyorum. Üçgen kelimesini ișitiyorum ve umumiyetle üçgen kavramını görüyorum.

Demek ki manası olan objeleri bir görüș haline getirebiliriz. Bu görüșlerin duyuma dayandırılması șart değildir; müdrikeye (zihne) dayanan bir görüss, de olabilir. Çünkü ben ancak tekil olan bir tek üçgeni zihni bir görüșle görebilirim. Umumi bilgiye sahip olmamız da buna istinat eder. Burada tümel bilgiye taalluk eden bir tikel bilgimiz mevcuttur. Bir ses aslında işittiğim sesin gereği olarak değil, bütün seslerin gereği olarak geçerlidir. Bir üçgenin açıları madde ile kaim değildir. Bu öyle bir önermedir ki bütün üçgenlerde geçerlidir. Eğer biz bildiğimiz münferit objelere istinat etseydik umumi kaziyelere nasıl varabilirdik? Hakikaten biz umumi bilgiye bu objelerin umumi tarafı ile varabilirdik.

Demek ki Husserl'e göre iki türlü önerme vardır. Umumi ve istikrai önermeler, istikrai șekilde umumi (genel) önermelerimiz olmasaydi; istikraya dayanan (tümevarıma dayalı) bir önerme de olmazdı. Mahiyetleri icabı bu umumi önermeler vardır. Demek ki bütün ilimler evvela bir tür (umumi mahiyet kanunları) üzerine kurulurlar. Bunun yanında bir de empirik kanunlar vardır, biz bu mahiyet kanunlarını mahiyetin misaline bakarak elde ediyoruz.

Her ilim evvel emirde biraz bu mahiyet kanunlarından hareket etmelidir. Misal: riyaziyat, idrak, ihsas ve hükümle meșgul olur. Bunu tetkik için soru șöyle sorulmalıdır. "Genel olarak, ihsas, idrak nedir? Psikoloji evvela bu mahiyetleri tetkik etmelidir. Misal: Dinleri tetkik eden ilimlerde șöyle sorulur. Umumiyetle din nedir? Her dinde aynı olan bir șey var midır?"

Bunları din ilmi tespit etmelidir. Aynı olan bir șey varsa, bunları din ilmi tespit etmelidir. Mahiyet kanunu fenomonolojiden eskidir; fakat fenomonoloji bazı kanunların tatbik sahasını genișletiyor. Her ilmin bir sahası vardır ki Fenomonoloji; bu mahiyet kanunlarıyla uğrașır. Söylediklerimizi hülasa edelim: Demek ki görüș haline gelen, mahiyete taalluk 
eden bir șekilde manaya istinat ediyoruz. Bu da zihni bir görüșe dayanır. Burada gördüğümüz mahiyetlerdir. Mahiyete taalluk eden görüș ile elde ettiğimiz bilgi, mahiyet kanunlarıdır.

$\mathrm{Bu}$ kanunları empirik kanunlardan ayırmalıdır. Ampirik kanunları münferit olan hareketlerden elde ederiz. Riyaziye empirik ilimlerden farklı olarak mahiyet kanunlarını da ihtiva eder. Diğer ilimlerde de mahiyet kanunları mevcuttur. Şimdi hareket noktasına dönelim. Üç kavramdan söz etmiștik. Süje-obje, șuur ve akt... Bu üç kavramı ihtiva ettiğimize göre, bu bir mahiyet önermesidir. Burada Husserl ile materyalizm arasında bir tezat görüyorsunuz ki; bütün felsefe tarihinde bu mesele ile meşgul olunur. Husserl tekrar Eflatun'a geri döner.

Ancak Husserl yeni bir felsefenin mümessilidir. Peki, bunlardan hangisi haklıdır? Bu sual hiçbir zaman halledilemeyecektir. Biz bu iki nokta-i nazarın esaslarından hareketle ne gibi neticelere varıldığını göreceğiz.

\section{Suje, Obje ve Akt}

$\mathrm{Bu}$ defa șu noktayı göz önünde bulunduralım. Fenomonoloji șuur hakkında ne yapmak istedi? Aynı zamanda șuurla beraber, objeler hakkında da bir bilgi almak istedi. Fenomonolojiye göre her șuur bir obje șuurudur. Sual obje nedir? Bilgide ben'in de mevcut olması ve ben'le obje arasında bir aktın olması lazımdır. $\mathrm{O}$ halde șuurun muhtelif mertebeleri var demektir. Mesela nehir bir objedir. Hissediyorum. Ellerime parmaklarıma alıyorum. Paris'in hissettiğim bir yer olduğunu anlıyorum. Bu muayyen bildiğim bir obje, hissettiğim bir șeydir. Fakat bu objeye müteveccih olduğum isim dolayısıyladır. Bu isim bana objeyi tercih ettiriyor. Buna karşın Paris'e gidiyor ve Sen nehrini görüyorum. Șimdi Paris'e gittiğim zaman, önce tespit ettiğim șeyi görüyorum.

Demek ki iki șey karșısındayız. Evvela nehri görmeyi kastediyorum. Bir de onu tüm endamıla görüyorum. Evvela bu șey, bu obje kasd ve tasavvur edilmiș sonra bu obje bütün endamıla dirilmiștir. Bu haliyle burada iki akt vardır. a-İsim veren ișaret eden akt b-İntinuitif görüș haline gelen akt. Bunlar arasında da bir ilișki vardır. Șu anda ben Paris'te değilim fakat kendim bunları șimdi hatırlayabilirim. Burada da objeyi hatırlama aktım aynen vermiștir. Diğer taraftan, objeye verdiğim isim içerisinde az veya çok fantezi olabilir. Misal olarak bir söz alalım: tarihi bir kitap 
okuyorum; bu kitabı okurken cümleleri muayyen bir anlayıșla anlıyorsunuz.

Burada kelimelerin ve dolayısıyla cümlelerin manasını anlıyorsunuz. Bu esnada bazı fanteziye dayanan tasavvurlara dikkat ediyoruz. Fakat bu fanteziye dayanan kelimelerle de iktifa edebiliriz. Diğer taraftan fiziğe ait bir kitap okuyor muayyen birini iyi karșıllyor ve șüphesiz tasavvur ediyorsunuz. Yine burada fanteziye ihtiyaç duyuyorsunuz. Bu kitabı o okurken aktlar anlamamıza az veya çok yardım ediyor. Demek ki bir kitap okurken evvela kelimeye, sonra hayale ve fanteziye dayanan tasavvurlar vardir.

Husserl'e göre; "biz münferit objeleri olduğu gibi umumi objeleri de idrak edebiliriz" demiștik. Misal: üçgeni (müselles) evvela münferit olarak tetkik edebilirim. Burada iki objeden birini misal olarak alır ve oradan da umumi bir müsellese varabilirim. Münferit müsellesleri idrakle alırım. Umumi müselles mefhumunu ise görüyorum, düșünüyorum. Düșünme de bir görüștür. Burada Husserl için mühim olan "mabiyet görüșü" meselesine var1yoruz. Riyaziye, umumiyet itibarıla müselles hakkında tetkikler vaaz eder. Eğer münferit müsellesleri idrak etmemiș isek, bunu anlamamızın imkânı yoktur. Fakat yalnız bu objeler sahası gibi, umumi objeler sahası da mevcuttur.

Husserl'in tabiriyle demek ki; "insan yalnız münferit/tekil objeleri değil de umumi objeleri de idrak eder." Hâlbuki hayvan yalnız münferit objeler hakkında bir șuura sahiptir. İnsan ise münferit objede kalmaz, umumi objeleri de idrak eder. Yine bundan dolayıdır ki, insan haricindeki varlıklara kelimeler sayesinde ulașmaya muvaffak olur. Çünkü insanın kelimeleri münferit objelere olduğu kadar umumi objelere de teșmil ediliyor. Umumi mefhumun da hakkından gelebilir; ancak insan bunu yapabilir yani münferit olaylarda küllinin șuuruna varabilir. Hâlbuki bunu münferit vakıalarının idraki ile elde edebiliriz. İnsan umumiden hareket ederek münferit hallere de teșmil edilebilir. Demek ki münferit meseleden umumiye, umumiden tekrar münferide gelebilmek ancak insanların kabiliyetiyledir.

Düșünme de aynı zamanda bir görüștür. Fakat her șeye istinat etmeyen bir görüștür. Görüyorsunuz ki, burada Kant ile Husserl arasında bir fark vardır. Kant'a göre düșünme ne demektir. Kant ontik șekilde düșünme ile düșünmenin bağ kurma anlamı arasında bir fark görür. Düșün- 
me ilișki temin eden bir faaliyettir. Düșünme münasebet eden bir faaliyettir. Düșünme demek objeler arasında münasebet temin etmek demektir. Biliyorsunuz ki düșünme farklı mefhumlarla olur. Mefhumlar ne demektir? Mefhumlar tasniflerdir. Çünkü umumi bir mefhum birçok münferit s,eyleri ihtiva eder.

Şu halde umumi mefhumlar, münferit objelerin toplanıp aralarında bir münasebet tesis ettirilmesiyle meydana gelir. Düșünme aynı zamanda sonuç ve illet aletleriyle çalıșır. Yani bunlar düșünmenin șartlarıdır. Fakat burada bir șeyle diğer șeyin aynı olması için, o iki șeyin arasında nasıl bir münasebet temini lazımdır. $O$ halde düșünmek için önce hazır olarak verilen bir malzeme mevcuttur. İllet/sebep ile sonuç arasındaki bağı düșünme kurar. Düșünme bunların mühim șartlarıdır. Mesela: illet ve eser arasında bir münasebet tesisi ederek kavramları yapar. $O$ halde düșünme mukayese ve münasebet tesis etmelidir.

Husserl'e göre düșünmek, umumi objeleri kavramak demektir. Fakat bu hasseye dayanan bir kavrama olmayıp, düșünmeye isnat eden bir kavrama ve görüștür. Husserl'e göre; illet ve eser/sebep ve sonuç dediğimiz șey, dahi görüș haline getirilebilir. Filhakika bunun neden ibaret olduğunu yașanmıș bir vakıada görüș haline getirebilirim. Diğer bir misal olarak da "zaruret/zurunluluk" kelimesini görüs, haline getirebilirim. Fakat ben zarureti tam yakalayamam lâkin zaruret mefhumunun neye delalet ettiğini derunî bir görüș objesi yapabilirim. Husserl'e göre gerek Kant'in ve gerekse Hume'un hatası șudur: Onlar idraki yalnız duyum (hasse) olarak anlarlar. Bundan dolayı Hume için eser ve illetin (sonuç ve neden) bir ilișkisi yoktur. Hume için ancak belirli bir șeye dayanan idrak mutası (verisi) olan șeyler vardır.

Neden ve sonuç arasında zorunluluk olgusu görülmediğinden dolayı Hume buna temas etmiyor. Husserl buna mukabil; "Biz zaruretle bir seyi kastediyoruz ve buna bir mana verebiliyoruz. Yani biz bunu görüss ve mana haline getirebiliriz" diyor. Husserl'e göre duyuma (ihsasa) isnat eden idrakleri değil, kategorileri de görüș ve idrak haline getirebilirim. Bu suretle Hume ve Kant'ın yanıldığını söylüyor. Çünkü Kant'a göre de idrak hasseye ait mutalardır. Kant'ta hasseye dayanan mutaya karșı bir faaliyet vardır ki; bu düșünmeye karșıllı (mukabil) idi.

Geçen derste ișaret ettiğimiz gibi Husserl, son devrinde daha çok 
Kant'a yaklașir. Kant felsefesinin transandantal idealizmi ile ne kasteder? Bunu diğer idealizmle realizmden nasıl ayırıyor? Bunun için Kant'ın mekân ve zaman fikrini görelim. Kant'a göre zaman ve mekân ideal șeylerdir. İdeal șeyler ile Kant acaba neyi kasteder? Ĕ̆er biz insan șuurunu reddedersek zaman ve mekân kaybolur. Çünkü șuur olmadan hiçbir șey mevcut değildir.

Göz olmadan renk mevcut olmaz. Gözün dünyası renklerden meydana gelmiștir. İșitme aktı, olmadan ses mevcut değildir. Ancak ișiten bir varlık olmalıdır ki, ses mevcut olabilsin. Demek ki dünya bizim uzvumuzun muhtelif aktlarına tabidir; (görme, ișitme, koklama gibi...) Görmeyen bir insan için görme, ișitmeyen insan için de ișitme dünyası yoktur. Göz dimağımız onunla vardır. Gözü olanlar mağaralarda bırakıldı̆̆ı zaman yașayamazlar. Fakat bu zaman ve mekân da aynı zamanda bir tasavvura tabidirler. Bizim tasavvur ettiğimiz her șey zaman ve mekâna bağlıdır.

Eğer tasavvurlar yanlıs, tarzda vuku bulursa, o zaman bunların zaman ve mekâna ihtiyaçları olmayacaktır. Mesela gözlerimiz ve kulaklarımız, görme ve ișitme dünyamız olmadan; zaman ve mekân ise șuurumuz olmadan mevcut değildir. Bizim tasavvur ettiğimiz dünya, bizatihi dünya değil șuura tabi bir dünyadır. Demek ki dünya muayyen bir șuurun mevcudiyetini șart koșar.

$\mathrm{Bu}$ idealizmin karșısında realizm bulunur; buna göre ise zaman ve mekân bize bağlı değildir. Realizme göre, zaman ve mekân insan șuuru haricinde vardır. İdealizmde ise, zaman ve mekân șuura bağlıdır. Fakat bu idealist istikamet Kant'ın evveline kadar hiç kimsede kati ifadesini kazanmamıștır. Kant'ın nokta-i nazarına göre, șuursuz zaman ve mekân mevcudiyetini kabul etmek mümkün değildir. Zaman ve mekân dâhilindeki bu dünya, bizatihi değil ancak şuur için mevcuttur.

Bu noktada Fenomonoloji iki istikamete ayrilır: İdealist ve Realist. İdealist istikamet, Husserl'in son eserlerinde tebeyyün eder ki; Husserl'in bu idealist hareket noktası Kant'ın da hareket noktasıdır. Ben bir objeye bakıyorum. Ben bir objeyi görüyorum. Ve bu obje etrafımdan ayrılıyor. $\mathrm{O}$ halde bir obje ne demektir? Acaba ruhta verilen (görü) bildiğimiz șey midir? Tekrar gördüğümüz șekilde bir șeyi göremeyiz. Fakat bu vahdet her yerde tekerrür ediyor. Muayyen bir ses ve muayyen bir renk ișitiyor ve görüyorum. Bunlar bir vahdetten ayrılamaz. Esas itibarıyla vahdet nedir? 
Bunun için birliği (vahdeti) temin eden akta dönelim. (Kendini oluşturan parçaları) toplayabilmek gücünden (kanuniyetinden) mahrum bir mahlûk vahdetten de mahrumdur. Sayamayan bir varlık için de sayılar (adetler) mevcut olamaz. Demek ki, muayyen aktlar icat edebilmeli ki, muayyen mefhumlar ortaya çıkabilsin. Vahdet ancak toplayabilen, yarılayabilen/bölebilen bir varlık için mevcuttur. Toplayabilen bir akt mevcut olduktan sonra, vahdetin de ne olduğu anlaşılır. Daha doğrusu vahdet kelimesi ortaya çıkar.

Demek ki muayyen sayılan toplanan dünya, muayyen aktların bünyesinde mevcuttur. Bu akt olmazsa dünya olamaz. Böyle bir dünya ancak muayyen bir obje ve bir süje için mevcuttur. Bu suretle șu neticeye varabilirim. Objenin mevcudiyeti süjeyi șart koșar. Obje dünyası idrak eden bir süjenin dünyasıdır. Görülüyor ki bu idealizm ile birlikte, realizm muayyen bir zaruretle tekrar ortaya çıkmaktadır. Yani Kant'ın nokta-i nazarı/bakıs, aç1s1.

Sizlere daha öncede anlattığım gibi, felsefe tarihinde zamanla birtakım yönelimler görülür. Bunlar felsefe tarihinde tekrarlanan yönelimlerdir. Heidegger'in I927'de yayınladığı zaman ve mekân hakkındaki eserinde de aynı durumla karșılașıyoruz. Burada da bașka felsefi fikirler mevcuttur. Bu konudaki eleștirilerden daha sonra söz edeceğiz.

İlk olarak onun felsefesinin esas noktalarını anlatacağım. Bunu ifade etmek için Heidegger'den değil de, Ortaçağ felsefesinden söz edeceğim ortaçă̆ felsefesi obje hakkında iki soru sorardı. Bu obje nedir? Bu bir masadır; eskimiș bir masadır. Bu soruyla kalınmaz. Obje hakkında diğer bir soru sorulur. Birinci soru objenin mahiyeti ile ilgilidir. İkinci soru ise objenin mahiyeti ile ilgili değil, var olușu ile ilgilidir.

$\mathrm{O}$ halde önümüzde duran bir obje için: $\mathrm{Bu}$ obje nedir? $\mathrm{Bu}$ objenin mevcudiyeti nedir? Sorularını sorarız. Bu obje hakikaten mevcut mudur? Zahirî veya fenomenal mıdır? Demek ki objede șu noktaları araștırırız: IObjenin mahiyetini; 2-Objenin mevcudiyetini.

Heidegger, Ortaçağdan mülhem olarak hareket ediyor. Bu durum aslında sadece Heidegger için geçerli değildir. Brentano da Ortaçağdan ve Aristoculuktan birçok tesir alır. Fenomonolojinin Aristo ile münasebetini Husserl'in hocası Brentano kuruyor. Fenomonolojinin esas görevi objele- 
rin mahiyet kanunlarını araștırmaktır.

Size anlattım ki, felsefede bir takım istikametler/doktrinler zamanla ortaya çıkıyor. Bunlar felsefe tarihinde tekerrür eden istikametlerdir. Bunun önemli bir örneğini, Heidegger'in 1927'de neșrettiği "Zaman ve Mekân Var mı?" eserinde görüyoruz. Buna karșı bașka felsefi fikirler de mevcuttur. Buna yapılan itirazlardan bilahare bahsedeceğiz. İlk olarak onun felsefesinde esas noktaları anlatacağım. Bunu ifade etmek için Heidegger'den değil, Ortaçă̆ felsefesinden bahsedeceğim.

Ortaçağ felsefesinde tetkik sahamıza giren obje iki cihete ayrılır. Ortaçağ felsefesi șöyle bir sual vaaz ederdi: Bu obje nedir? Bu bir masadır; eskimiș bir masadır. Fakat bu felsefede obje hakkında diğer bir sual sorulur ki, bu objenin mahiyetine müteallik idi. Diğer bir sual de objenin mahiyetine değil de mevcudiyetine taalluk eden bir sual oluyor.

(Brentano'ya göre) Fenomonolojinin esas vazifesi; objenin mahiyet kanunlarını tetkik etmesi değil, bu objenin kanunlarına neden olan mevcudiyetin mahiyet kanunlarına ehemmiyet vermesidir. Heidegger ise bașka yoldan hareket ediyor. Ona göre felsefe, bir objenin mahiyetini değil, mevcudiyetini de tetkik mevzu yapmalıdır. Ona göre felsefenin aslını teșkil eden (mevcudiyet) ve varlı̆̆ın ne olduğudur. Bunu tetkik için herhangi bir varlığın mevcudiyetini görüș vasıtasıyla (incelenebilecek) bir veri haline getirebiliriz.

Bunun için biz iki șeyden hareket etmeliyiz. Bu iki șey șudur: I- evvela kendi mevcudiyetini 2- herhangi bir objenin mevcudiyetini, ortaya koymak lazımdır. Ben kendi mevcudiyetim ile diğer bir șeyi tetkik edeceğim zaman, kendi mevcudiyetimin diğerlerinden farklı yönlerini ele alıyorum. Ben veya herhangi bir șey veya her süje ve objeler arasında esas bir fark vardir.

Heidegger'in yaptı̆̆ı bu ayrım bașka bir filozof tarafından da yapılmıștır. Bu Fichte'dir. Bu farkı felsefe tarihinden bahsetmek suretiyle daha derinleștirelim. Her devirde felsefe en derin bir niza/düalizm olarak kabul ettiği bir noktadan hareket eder. Misal: İlkçağ için bu nokta hangisidir? Antik felsefe için bu niza canlı ve cansız olandır. Nasıl oluyor da ayrı uzuv ve maddelerden hayat husule geliyor. Canlı ve cansız arasında fark nedir?

Yeniçağ felsefesinde ise en derin niza (kavga) șuurla madde arasında- 
dır. Diğer bir tabirle șuur dünyası ile șuur harici olan kavgasıdır. Descartes'tan beri ortaya șöyle mühim bir mesele çıkıyor. Nasıl oluyor da objeler hakkında bilgi sahibi olabilirim. Yani șuur nedir? Daha geliyoruz; 15. asırda bunların yerine diğer bir niza çıkıyor. Bu da "ben ve eşya” kavgasıdır.

Șuurun arkasında bir ben vardır. Yani bu șuur "ben"e aittir. "Ben"in karșısında eșya dünyası vardır. Burada ben ile eșya arasında mevcut bir uçurum vardır ki, bu kâbil-i telif olunmayan (uzlaștırılamayan) bir uçurumdur. İște Heidegger'in düalizmi ben-eșya düalizmidir. Bunu karakterize etmek için Heidegger, mevcudiyet (existance) ve mahiyet arasındaki farktan hareket ediyor. Her șey mahiyet bakımından tayin edilmiş bir șeydir. Bir kitap, bir çanta bir șeydir. Demek ki ilk defa karșıma çıkan sual bir mahiyet sualidir. Bir șeyin ne olduğu sualidir.

İkinci sual de, burada gördügüm șeyin mevcudiyeti meselesidir. Ormanda avcı ve bir kuṣ, görüyorum. Biraz sonra bunun rüzgâr tarafından sürüklenen bir yaprak olduğunu fark ediyorum. Bir insan zannettiğim șeyin yaklașınca ağaç gövdesi olduğunu fark ediyorum. Kuș ve insanı gerçek olarak gördügüüü zannetmiștim. Yaklașınca kuș değil yaprak, insan değil ağaç gövdesi olduğunu gördüm.

Şöyle bir neticeye varıyorum: Benim bir kuș ve insan olarak gördügüm bir zahirdir (görünüș), hakikat değil. Benim burada gördüğüm gerçek kuș ve insan değildir. Yine zahiri bir tasavvur vardır. Bazen de ișittiğim herhangi bir șeyin, emin olduğum vaziyeti yani onun mahiyeti vardır. Kendim hakkındaki bilgiyi yakalıyorum. Ben kendi mevcudiyetim hakkında aldanabilir iyim? Ben mevcudiyetimden hiç șüphe edemem. Hatta bu cihet benim mutlak olarak bildiğim yegâne șeydir. Çünkü benim mevcudiyetim hakkında șüphe edemem. Bu bilgi bir Yeniçağ felsefesinin bașında bulunan bir filozofun öğretisidir.

İște Heidegger, (Descartes'ın șuur hakkındaki bu fikirlerinin) kendi fikrini bozmadığı ve hatta bunlardan istifade ettiği kanaatindedir. Çünkü Descartes șuurda israr ediyordu: Ruhun düșünen bir șey olduğunda israr ediyordu. Bunu faal olarak bildiğimiz șöyle böyle bedihidir. Descartes'ın keșfedip de farkında olmadığı șey, düșünen șey olmayıp; aslında düșünen șeyin karșısında bulunan bir varlıktır. Şu mesele ile karșılașıyorum. Bir șey hakkında tetkik yaparken mahiyeti kati, mevcudiyeti kati olmalıdır. Sual benim için olursa, mevcudiyetim kati(kesin) fakat mahiyetim kati değildir. 
Eșyanın mevcudiyeti kesin bir hakikat olmayıp, daima bir "ben" i șart koșar. Ben ile eșyayı bir daha mukayese edelim: ben ile kitap arasında mukayese yapıyorum. Bu objeler ikinci sınıf șeylerdir. Çünkü her ikisinin işgal ettikleri mekân ayrıdır. Bu objelerin esasını teșkil eder. Ben șimdi diğer bir insandan kendimi tefrik etmek istersem, o da benim gibi bir insandır. Bu deminki gibi iki muhtelif mekân ișgal etmeyenden neșet etmez.

Bu iki insan arasındaki fark, ben ile sen arasındaki farktır. Ben ile sen arasındaki fark mühim bir farktır. Bu objeler arasındaki fark gibi, mekâna dayanan farka benzemez. Çünkü ben dediğim de bir insandır. Fakat bu insan kendisi için "ben" fakat benim için "sen"dir. Ben kendim için" ben"im bașkası için "sen"im. Bu "ben"in ihsas ettiği esastır.

Birçok masalar vardır. Bunlar tahta ve ayak gibi șeylerden terkip edilebilirler. Masa, umumi bir mefhumdur. Bu mefhumun ihtiva ettiği masalar, ancak objektif esbaba dayanan farklardan neșet eder. Acaba "ben" mefhumunun muhtevasında da tetkik yapilabilir mi? Acaba ben mefhumu da masa gibi umumi bir mefhum mudur? Bu șüphesiz böyle değildir. Herkes için tek bir "ben" vardır. Kafamızdaki diğer insanlar bir "sen"dir. Demek ki "ben" mefhumu birçok insan sahnelerini ihtiva eden umumi bir mefhum olmayıp yalnız "ben"i ihtiva eder. Bir "ben" ve "sen"e ișaret eder. Ben ile aynı zamanda insan mefhumunu da teșkil ederim. Fakat insan mefhumunu teșkil ettiğim zaman sebepler sahasına giriyor; "ben"den uzaklaşıyorum.

Şimdi de "Noumen"leri tetkik edelim. Evvela eșya ile onun vasıflarını; sonra da ben ile benim vasıflarımı tetkik edelim. Eșyaya misal olarak elimde tebeșir var. Bu tebeșirin muayyen bir șekli, faaliyet șekli var. Bu maddi bir șeydir, yani bir nesnedir. Filozoflar bundan bașka geriye; "bizatihi eșya kalır" dediler. Bir ben, bir fert kendi kendine yalnızdır. Ve bu yalnızlı̆̆ın da Allah'la bir münasebeti vardı. Çünkü dindar adamın tavırları da münzevidir ve Allah'la karșı karșıyadır. Ve diyor ki Hegel: İnsanı tarihi bir eșya yapıyor. Bu olamaz. Zira insan ferttir ve ancak Allah'la münasebettedir. Hegel insanları bir fert değil, bir eșya olarak kabul ediyor.

Başka bir bakımdan Hegel insanlar için üç temel tavır olduğunu söyler: 
I.Estetik Tavir: Estetik tavra haiz olan insan, hayatta mümkün olan her șeyden zevk almak ister. Bu insan aynı zamanda, an içinde yașayan bir insandır. Bunlar arasındaki insanların bazıları sathi, bazıları derindir. Sathi ve kaba olan kiși hayatta zevk alması mümkün olan her șeyi yapar. Bu sebep için deriz; eğer bu kiși zevk tatmayı manevi sahaya tevcih ederse; hayatını bașlıca bir zevk üzerine yașamaya tabi kılan bu insan, nev'inin en mükemmelidir. Fakat ne olursa olsun, estetik tavra sahip insan aslinda așağı mertebeye tabi olan ferttir. Böyle bir kiși ihtiyarlarsa, hayatındaki hata ve eksiklerinin șuuruna sahiptir. Çünkü bu insan hiçbir zaman tam olmamıștır.

2.Etik Tavır: Bu tavra haiz insan, böyle bir insan tipi hayatını muhtelif vazifelerin içinde ve onları halletmekte bulur. Bu kiși kendini cisminin hizmetine verir. Bu tip insan bir vazife șuuru içinde bulunur. Bu vazife kendisini avutmasına müessir olur. Biteviye vazifeleri tahkike uğrașır, yani an içinde yașamaz. Hegel'in insanı Kierkegaard'a göre bu etik tavrı haiz insandır. Hegel șöyle der: "tarihi Allah yapar ve insan da onun atıdır."

3.Dini Tavır: Bu tavrı takınan insan, dindar insan cisminin ve her șeyin fevkinde bir șeyin mevcudiyetini kanidir. Aynı zamanda dindar insan, daha bașka șeylerin de kendine tevcih edilebileceğini bilir. Bu tabir, kayıtsız șartsız ișlenen șeydir. Bütün tarihte bu tip insanlar vardır. Bunlar Allah'in azameti için her șeyden sarf-1 nazar etmiștir.

İnsan ölüm meselesini göz önünde bulunduruyorsa, șüphesiz șu tavrı, yapılması istenen șeyler karșısında bulunduğunda daha çok hisseder. Kierkegaard'ın bütün tefekkürü, bu dini șuur tarafından tayin edilmiștir. Ona göre insan, dini yașamalıdır. Ancak insan bunu yaparsa, hayatının derinliğine vasıl olur. Etik tavra haiz insan, estetik tavra haiz olanın önündedir. Fakat dindar insan yine bunların hepsinden büyüktür.

Görüyorsunuz ki Heidegger, Kierkegaard'ın bu fikrini almaz. "mevcudiyet" ve "endișe" fikirlerini alır. Fakat Kierkegaard'ın felsefesinden bunları kaldırırsak onun șahsiyetini silmiș oluruz. Fenomonoloji bahsini kapatarak diğer bir bahsi açıyoruz. Bu bahsin adı: "Tabiat İminin Felsefe Üzerindeki Tesiri"dir.

Tabiat ilimleri zamanımızda büyük bir inkișaf geçirmektedir. Bu inkișaf hem fizikte hem de biyolojidedir. Son zamanlarda biyoloji ve fizikte 
önemli bir inkılâp olmuștur. Biyolojide vitalizmin yeniden canlandığını gördük. Șüphesiz ki bu bütün felsefeye de tesir etmiștir. Hal-i hazırda felsefede bazı inkișaflar vardır ki, tabiat ilimlerindeki bu inkișafı göz önünde bulundurmadan onları anlamak mümkün değildir.

Evvela biyoloji cephesindeki tartıșmalarla bașlayalım. Burada göze ilk çarpan vitalizm ve mekanizm nizalarıdır. Vitalizm ve mekanizmden ne anlıyoruz? Mekanizm nazariyesine göre, uzviyette cereyan eden hareketler mekanik nizama tabidir. Uzvumuz kurulmuș bir makinedir. Vitalizm nazariyesine göre de organik madde bir makine değildir. Buna göre vücudumuzda cereyan eden karakterler, fiziki ve kimyevi tesirlerin tamamiyla mutlak kontrolü altında değildir.

Çünkü uzviyette yeni bir șey ortaya çıkıyor. Bu yeni unsur, șeylerdeki karaktere hâkim olan kanunlar fiziki ve kimyevi kanunlarla teșekkül etmeyen kanunlardır. Bu devirde böyle bir fikrin hâkimiyeti kimya sayesinde olmuștur. Çünkü kimya kurulunca yalnız uzviyetlere istinat edilen birçok cisimleri gayrı uzvi maddelerden istihsale başladılar.

Hatta bugün bile böyle albümin maddeler suni șekilde istihsal edilirler. Bu noktadan hareket edenler, uzviyette vukua gelen maddeler kimyevi, fizikidir diyorlardı. İkinci derecede mekanist nazariyeyi kolaylaștıran, Darwinizm nazariyesinin ortaya çıkmasıdır. Darwinizm de hayvan ve insan türlerinin menșei meselesi mevzu bahistir. Darwin bu menșein mekanik kanunlara göre cereyan ettiğini kabul ediyordu. Bir hayvanın yavruları az veya çok birbirine çekerler. Haddizatında birbirinin aynı değildir. Bir hayvanda gördüğümüz değișiklikler kısmen hayvanların ırki özellikleri olarak ortaya çıkmıșlardır. Hayata hizmet eden organizma inkișaf ederek veraset suretiyle intikal ediyorlar.

Demek ki, bu küçük değișiklikler sayesinde bașka yeni hayvanların çıkmasına neden oluyor. Küçük hadiselerin tesadüfî olușu ve mekanik kanunlar yeni bir nevi meydana getiriyor. Mekanizm tesadüfen yeni neviler ortaya çıkarıyor. O halde mekanizm ve tesadüf uzvi hadiseler halinde bulunuyor. Bu insan ve hayvan nevilerinin nasıl meydana çıktığını ifade eden bir nazariyedir. I860 tarihinde Darwinizm büyük bir tesir yaptı. Bilhassa hayat hakkındaki mekanik telakki üzerinde daha kıymetli tesirler icra etti. 
I8, asrın sonlarında ı9. asrın başlarında yeni bir nazariye ortaya çıktı: Vitalizm. Bunlara göre gerek hayvan gerek bunun uzuvlarından (organ) istihsal edilenler yine hayata tesir istihsal edemezler. Bizim elde ettiğimiz Albumin canlı değildir. Biz uzvi (organik) olanı cisim olarak istihsal ederiz. Fakat hayat ve onlardaki canlılık istihsal edilmez. Hayata zerrede rastlarız ve ona "bir canlı nev'inin mahsulüdür" deriz. Hiçbir zaman hayatın, canlı olanın dölünden hâsıl olduğunu göremeyiz. Hakikaten kimyacılar da tecrübelerinde misal olarak canlı bir uzvu istihsal edememiștir. Darwinizm de vitalizmin karșısındadır. Çünkü nevilerin tesadüfen ve mekanik bir vasıta ile ortaya çıkması șüpheli bir vaziyet alıyor.

Hâlbuki bizim üzerinde durduğumuz șey șudur: Sanki onun içinde bir amil varmıș ve değișmeye tesir eder olmuș gibi görünür. $O$ halde fiziki dünya ile hayvanlar dünyası arasındaki fark șudur: hayvanlar dünyasında faaliyet gösteren bir amil mevcuttur. Vitalizm diyor ki: "Organik (uzvi) cisimlerde yani canlı cisimlerde öyle amiller (özellikler) vardır ki bunların tesirleri fiziki ve kimyevi kanunlara indirgenemez (irca edilmez). Filhakika bu gibi amiller vitalist nazariyenin lehindedir.

İlk defa vitalist olan Hans Driesch vitalizmin vaazıdır. Driesch'e göre, uzvi olan her șey gayri uzvi olandan esas itibarı ile ayrıdır. Bir buhar makinesi tetkik edelim. Bu makine muhtelif parçalardan teșekkül eder. Mesela buhar kazanı, motoru, tekerlekleri gibi... Ben bu makinenin bu kısımlarını birbirinden ayırır ve tekrar birleștiririm. Makinenin ișlemesi parçaların birbiriyle uyumlu ve beraber çalıșması sayesindedir. Ama bu makineyi teșkil eden parça kırılırsa ișlemez. Değiștirmek lazımdır. Fakat makine hiçbir zaman bu bozuk olan kısım tamir edilmeden ișlemez.

Hâlbuki uzvi olanlara ait olan böyle bir kabiliyet diğer bir tarafta bulunursa, organizma onun vazifesini de üzerine alır ve ișlemeye devam eder. Her organizma da vukua gelen vaziyet de bir tağyir yapar. Kendini yenileștirir. Böyle bir vaziyet karșısında tağyir ve aynı zamanda makinenin parçasını tamir eder. Uzvi olan bir cisim cüzi hücreler ikaz eder. Ve bunlar bütün bir uzuv olarak meydana çıkar.

Demek ki organizmadaki bu kabiliyet bütün organizmaya șamildir. Onun tarafından idare edilir. Organizmde her șey bütün tarafından tayin ediliyor. Mesela, cüzi cisimlerde organizma kabiliyeti ihata eder ve yeni bir organizmaya bașlayabilirler. Makine de gayri uzvi olanda böyle bir 
kudret ve kabiliyet yoktur. Çünkü bir makinede noksan olan bir parçanın yerine diğer bir parça geçemez.

Driesch belirli bazı deneyler yapmıștır. Bilhassa denizkestanesi denilen hayvan üzerinde denemeler yapmıștır. Böyle bir denizkestanesinin yumurtası ikiye bölünürse her iki kısım da hayat tașır. Hatta I/4 bolünse bile inkișaf kabiliyetindedir. Fakat yumurta 4'e bölünmüș ise, 4 tane denizkestanesi hâsıl eder. Demek ki birer birer parçaların kuvveti bütündeki kuvvete sahiptir.

Bundan şu netice çıkar: Birincisi; Uzvi (organik) ve gayri uzvi (inorganik) âlem arasında esasen bir fark yoktur. Ancak gayri uzviden uzvi teșekkül edemez. İkinci olarak ise; Organizmada mevcut bir kuvvet vardır ki, bütün husule gelir ve parçaları teșkil eder. Bundan Driesch șöyle bir netice çıkartır. $\mathrm{O}$ halde uzvi hayatta hususi bir amil vardır ki, gayri uzvide bu yoktur. Bu amil bütünde ve onun parçalarında aynen vardır.

İște buna Driesch, Aristo'nun tabiriyle "entelekya" der. Çünkü bu entelekya Driesch'e göre șuurun da esasını teșkil eder. Her canlı hayvanda bir șuur vardır. Ölü ve canlı tabiat ruh sayesinde teșkil edilirler. O halde bu ruh evvela, hayat hadiselerinin esasını, ikinci derecede de șuurun esas1nı teșkil ediyor. Demek ki canlı olmayan bir gayrı uzvi tabiat mevcuttur. Gayrı uzvi olanlarda her parça kendine mahsus bir "kuvve-i tekvin"e maliktir. Filhakika her uzvi olan da gayri uzvi olanları teșkil ederse de, faal olarak ruha maliktir. Bu ise yeni vitalizmin esas fikirlerini olușturur.

Bu nazariyeye șöyle bir itiraz yapılabilir: Driesch'in ruh dediği șey kazanılmıș bir șeydir. Bu kazanılmıș șey, idrak sahasına dâhil olamaz. Buna karșı diğer bir șeyden bahsedelim. Neptün'ün nasıl keșfedildiğini biliyor musunuz? Biz Uranüs'ün hareketini müșahede edebiliyoruz. "Buradaki mibrakda manzumi (düzenli) șeyler görünüyor" diye bir Fransız astronom "orada bir bașka yıldız bulunmalıdır" diyordu.

Hakikaten bu astronomun yerine diğer bir astronom Neptün'ü buldu. İște bu bulușumuz (istihraç edebildiğimiz șey), bir "entelecheia"dan ibarettir. Neptün, bulduğumuz (istihraç edebildiğimiz) teleskop vasıtasıyla keșfedildi. Șimdi Driesch'in istihraç ettiği (keșfettiği) "entelecheia"ya bakalım. Yıldızda olduğu gibi, onu da istihraç edebilir miyiz? Yani onu mikroskopla görebilir miyiz? Edemeyiz. Çünkü burada istihraç edilen șey 
henüz keșfedilmedi. Yalnız keșfedilmez kalacaktır. Böyle bir istidlalin tecrübe ile kabil-i tahkik olacağı da düșünülmez. Bir faraziye kurulmuștur. Fakat hiçbir tecrübe tarafından tahkik de edilmemiştir. Bu onun ortaya koyduğu nazariyenin faydasız tarafıdır.

Bu itiraz neo-vitalistler tarafından Driesch'e karșı yapılmıștır. Bu filozoflara göre doğrudan doğruya tecrübe ile tahkik edilmiş nazariyeler ortaya konulmalıdır. Bütün zaman için ebediyen meçhul kalacak nazariye ortaya koymak faydasızdır. Tecrübe ile kabil-i tahkik olmayan nazariyelerde böyle bir taraf daha vardır. Bu vitalizmin inkișafı diğer bir istikamete tesir etmiș ve önemli neticelere varmıștır. Bu tesirin ait olduğu şahıs ise, Fransiz filozof H.Bergson'dur.

\section{Henri Bergson (1859-194I): (14-04-1944)}

Vitalistlerin ilmi istikametinden ayrı olarak bir felsefe sistemi kuran Fransa'nın en meșhur filozoflarından biri olan Bergson'dan bahsedeceğim. Bütün büyük filozoflarda karakteristik taraf bütüncül (vahdetli) bir sistem kurmaları ve bunu da diğer alanlara tatbik etmeleridir. Misal olarak Aristo'yu zikredebiliriz. Aristo'da mühim olan kâinatta olan șeyi tekâmül fikrine göre istihraç olmuștur. $O$, bütün șuurdan mahrum maddelerden hareket ederek Allah'a kadar variyor. Ve bu anda muhtelif mertebelerin mevcudiyetinden bahsediyor. Bu tekâmül fikri Aristo'nun bütün felsefi sistemine esas olmuștur. Her șeyi onunla izah etmiștir.

Tekâmül fikrini felsefenin merkez noktası yapan diğer filozof da Hegel'dir. Onun felsefesi de tekâmüle dayanır. Fakat Ondaki bu tekâmül dinamiktir. Tabiat ve insan sahasından bașlayıp, mutlak sahasına kadar uzanır. Descartes'ı düșünelim. Descartes'ın hareket noktası nedir? Bütün varlığ ruhu cisimden ayrı bir varlık olarak tasvir eder. Bu düalist sistemle o, bütün hadiseleri izaha çalıșır. Düalizm onun esas prensibidir.

Spinoza ise bunun tersine olarak âlemi bir vahdet teșkil eden șey olarak alır. Bu vahdetle diğer var olan cisimlerin münasebeti, denizdeki dalgaların denizle münasebeti gibidir. Bütün bu filozoflarda dikkate șayan bir șey vardır, o da muayyen nokta-i nazara sahip olmaları ve diğer șeyleri ona göre izah etmeleridir. İște bu Bergson için de karakteristik bir noktadır. Bergson da kâinatta bir tezat görür. Fakat bu tezat Descartes'ta olduğu 
gibi iki cevherin tezadı değildir. Tekessür(çoğalan) eden bu amiller bir bütünlükten ibarettir. Böylece $\mathrm{O}$ bütün gerçekliği, bu tezadın muhtevası içerisine alır. Zaman ve mekân, madde ve șuur, gayri uzvi tabiat ve uzvi tabiat aynı tezadın tezahürleridir. İlk önce zaman ve mekândan hareket edelim.

\section{Zaman ve Mekân}

Kant'tan beri zaman ve mekân ayrı tarzlar ve șekiller olarak kabul ediliyordu. Leibnitz (Gottfried Wilhelm Leibnitz (1646 - I716) için zaman ve mekân nizam șekilleridir. Diğer var olanlar ondan tanzim edilir. Kant için zaman ve mekân idrak şekilleridir. Newton için de zaman ve mekân diğer cisimleri ihtiva eden bir șeydir. Burada esas olan zaman ve mekânın aynı tarzda olması meselesidir. Bergson zaman ve mekânda bir aynılık değil de bir tezat görür. Ona göre mekân sabit olan ve kendi kendine sükûna malik olan bir șeydir. Hâlbuki zaman hareket halindedir ve daima değișmektedir. Hatta zaman kendisi bir hareket bir akıștır. Mekânda bir notadan diğerine her zaman gidebilir ve ilk hareket noktasina gelebilirim.

Hâlbuki zamandaki bir nokta hiçbir zaman olmayan ve ancak o anda mevcut olan bir noktadır. Zaman mazi olana tekrar dönemez. Mekânda bir nokta diğerini yaratamaz. Mekânda her nokta ezelden beri mevcut olan bir noktadır. Hâlbuki zamanda her bir nokta, yeni bir noktaya bağl1dır. Her zaman noktası yenidir. Çünkü o nokta bir an sonra geçecektir. Mekân yaratıcı değildir; zamanda yaratıcı bir kudret vardır. O halde zaman ile mekân arasında mutlak bir tezat vardır.

Aynı tezadı biz madde ve șuurda da bulabiliriz. Madde nedir? Maddeden ne anlıyoruz? Descartes maddeye bir yer kaplama özelliği atfediyordu. Bundan bașka madde, sabit kalan kaybolmayan bir șeydir. Madde için șöyle söyleyebiliriz. Madde mekânda sabit kalandır. Demek ki madde, mekânın haiz olduğu bütün vasıfları kendinde topluyor. Hâlbuki șuur mekândan mahrumdur. Bu vasıf Descartes tarafindan tespit edilmiștir. Bütün ruhi vakıalar (ihsas, idrak, vb.) mekândan mahrumdur. Mekânın her hangi bir noktasından tecrit edilmiștir. Hâlbuki zaman amili, şuur muhtevalarından ayrılmaz. Ruhi olan her șey canlı bir akıș teșkil eder. Şuur daima bir tahavvül geçirmektedir. Maddenin sabit olmasına ait kavramlar vardır. 
Bu madde âleminde de bir noktadan hareket ederek, diğerlerine gider ve tekrar aynı noktaya gelebilirim. Hâlbuki șuur herhangi bir anı tekrar etmeyen bir andır. Ben șuurumun mazisine tekrar dönemem. Bir șuur hadisesi ile șuandaki șuur hadisesi arasında fark vardır. Maziye ait șuur hadisesinde, maziyi tahattur ettirecek diğer bir hadise vardır. Șuandaki șuur ile geçmiș șuur arasındaki, fark iște "Ben"den kaynaklanır.

"Ben"in bu günkü mevcudiyeti bir sene evvelkinin aynı değildir. Hiçbir șuur vakıası tekerrür etmez. Bir fizikçi yenilik yaptığı zaman, tekrar edildiği vukuatla sabittir. Hatta tekrar etmek hassası fiziki kanunların mahiyetine aittir. Madde âlemine ait bütün șeyler, prensip itibarıyla tekrar edilebilir. Hâlbuki herhangi bir șuur vakıası aynı șekilde tekerrür etmez. Her ruhi vaka bir defaya mahsus ola bir daha dönmeyen bir karakter tașır. Görüyoruz ki, zaman ve mekân arasındaki tezat, madde ve șuurda da vardır. Çünkü bütün ruhi vakalar zamanın, cismi olanlar mekânın damgasinı taşır.

Diğer bir noktada da tezat vardır. Maddi olan âlemin tesir etmediğini söyledim. Yani cisim tesir etmez. Şuradan buraya itilen basit bir șeydir. Hâlbuki șuur tesir eden bir șeydir. Şuurdan tesir ve iradeyi kaldıramayız. Demek ki bu öyle bir akıștır ki, șuur ve irade tarafından tașınmaktadır. Ruh aynen zaman gibi yaratıcı bir vazifeye maliktir. Hâlbuki madde âlemi yaratıcılıktan mahrumdur, mekâna yaklașmaktadır. Aynı tezada uzvi ve gayri uzvi arasında da rastliyoruz.

Gayri uzvi olan bir varlık ile uzvi olanı mukayese edelim: Gayri uzvi bir cisim kendi kendine kalırsa değișmez. Uzvi olan cisimde zahirde değișmez gibi görülür. Fakat bu uzvi olanın zahirde sabit kalmasına mukabil daima değișen bir taraf vardı. Benim kendi vücudum, dünün aynı değildir. Vücudumun bugünkü terkibi, dünkünün aynı değildir. Çünkü ben yeni gıda aldım, eskilerini sarf ettim. Demek ki yașayan vücudum daima değișiklikler içindedir. Demek ki vücudumda ölen ve dirilen bir taraf vardır. $\mathrm{O}$ halde uzvi olan, yeniden inșa faaliyetine maliktir. Gıdalar vasıtasıyla nefes ile yeni terkipler vücuda gelir. Canlı olan cisim cansız olanın tam zıttadır. Uzvi olan cisim daima yeniden bir șey yaratmaktadır. Biz uzvi cisimden şöyle bir vakayı tespit ediyoruz. Her uzvi alanda bir gelișme bir gerileme gözlemliyoruz.

Biz münferit değil de bütün hayvanlar silsilesini alırsak aynı șey te- 
kerrür eder. Demek ki, biz uzvi cisimlerden değil de, bütün canlı varlıklardan bahsederek aynı șeyi müșahede edebiliriz. Bütün canlı olanlar tekâmül fikri çerçevesine ithal edilmiştir. Fakat bu tekâmül fikri hakkında șöyle sual sorulmuștur. Bu tekâmül gayeli midir, değil midir? Aristo'nun tekâmül fikri ortadadır. Onun fikrine göre tekâmülde daima bir terakki vardır. Biz böyle bir metotla nebatları ve hayvanları da tetkik edersek șöyle bir neticeye varırız: Tekâmül tek hücreliden bașlayarak insanlarda zirveye varmıștır.

Bu tekâmül hakikaten bu șekilde midir? Bergson'a dayanarak tetkik edersek böyle olmadığını görürüz. Tekâmül tek hücreliden, insana bir hattı istikamete varmaz. Bu fikrin yanı bașında, Darwin'in nazariyesi vardır. Ona göre bu tekâmül tesadüfi olan bazı unsurlar sayesinde oluyor. $\mathrm{Bu}$ küçük unsurlar bilahare, bir gaye, bir fayda olarak kendini gösterir. Bergson șöyle bir sual soruyor: Darwin'in dediği doğru olsa, tabiatta canlılar âlemini nasıl göreceğiz? Darwin'i kabul edersek tekâmül, bir hatt-1 mütekessir (farklı yollar) șeklinde görülür.

Diğer taraftan bakılırsa, canlılar âleminde karma karıșık bir tekâmül de yoktur. Ĕger biz canlılar âlemindeki tekâmülü tetkik edersek, bu adeta bir ağacın dallarına benzer. Muhtelif șubelere ayrılır. Oldukça aynı istikamette uzanırlar. Demek ki kökü muhtelif dallardan teșekkül ediyor. Bunlar aşağı yukarı aynı olmak üzere etrafa yayılıyor. Diğer bir misal alalım: bir nehir, bu nehrin bir menșei bir özü vardır. Nehrin suyu, mukavemetlere maruz kalarak parçalanır.

Yerden bir menșein çıktığını düșünelim: Yerden kaynayan bu su arzın üzerine muhtelif mukavemetlere bağlı kalacak fakat așağı yukarı aynı istikametlere akacak. Nebat ve hayvanlardaki tekâmül aynen su ve ağaçtaki tekâmül gibi olmaktadır. Nasıl ki su bir menședen çıkar. Ve kuvvetle çıkıyor ve dağılıyorsa, insanlar ve hayvanlar sahasında da böyledir.

Bu su dağılınca muhtelif mecralar husule getirmesi, hayvanların nevilerine tekabül (türlerine karșllık gelir) eder. Hayatın bu akıșının karakteri, zamanın karakterine benzer. Șimdi biz zaman ve mekân, uzvi ve gayri uzvi, madde ve șuur olmak üzere bu üç zıtlı̆̆ı nispet ediyoruz. Bu zıtlıkların bir tarafında yaratıcı bir taraf vardır. Diğer taraftan șayet bir kanun varsa; gerçek olan her șey bu iki nispetle hareket eder. Bu yaratıcı olan kuvvet ona karșı geliyor. O vakit yeni bir kuvvet doğuyor. Biz bunu her 
tarafta görüyoruz. Bunlardan birincisi yașayan bir kuvvet; İkincisi ise basit mukavemet eden kuvvettir.

Umumi mefhumlardan hareket edilerek; istikbale ait münferit bir hadiseden, önceden olacaklar tayin edilir. Zaten rasyonel bilgi her yerde aynı neticeleri veren bilgidir. Rasyonel bilgi, istikbale ait hükmünü, mazideki müșahedesine göre verir. Çünkü rasyonel bilginin, objesi mekâna, yani maddeye dayanır. Çünkü rasyonel bilgi ancak umumi mefhumlarla ifade edilebilen bir șeydir. Farz edelim ki yeni bir șey zuhur etti. Bunu diğeri gibi tetkik edemez. Zira rasyonel bilgi tekâmül edeni tetkik etmez.

Ĕ̆er tabiatta yaratıcı bir tekâmül varsa ki, șuur ve zaman bu yaratıcı amillerdendir. Tabi tabiat iki amilden teșekkül etmiștir. Bir sabit kalan, diğeri değișeni teșkil eden, tabiatı amillerin ancak birisi yani sabit kalanı rasyonel bilginin mevzuu olabilir. Fakat Bergson'a göre yalnız rasyonel bilgi olmayıp, bir irrasyonel bilgi de vardır ki, buna o intuitione (sezgisel bilgi) der. Bu bilgi insanlarda vardır. "Irrasyonel bilgi olmazsa ĕger, rasyonel bilgi de olmaz" der. Mesela ben kendi vücudum hakkında evvela, bazı șeyleri bilirim.

Fakat buna istinat etmeden fiziki ve fizyolojik tetkik yapmadan da kendi "benliğim" hakkında insiyaki bir bilgim vardır. Mesela, elimi ve ayaklarımı nasıl harekete getireceğimi biliyorum. Demek ki bilmek, bilinecek șeye hâkim olmaktır. İlmin maksadı, bilinecek șeyleri bilinen cihetlerin altına koymaktır. Bu manada da kendi bedenime hâkimim. İstediğim zaman, bir uzvumu harekete geçirebilirim. Bunun manası bilinen șeye hâkimim demektir. Mesela bir teknisyen bildiği fizik kanunlarına dayanarak bir makineyi ikmal eder. Böylece aynı zamanda, kendi vücudunu ne șekilde hareket ettireceğini de bilir. Lâkin teknisyen bunu, kendine ait uzuvları hareket ettirmek için bildiği kanunlara göre değil, insiyaki (refleksi) olarak yapar.

Demek ki evvela harici cisimlere ait bilgi vardır ki, bu bilgi müșahede (gözlem) sayesinde olur. Bir de kendi bedenim hakkında bilgim vardır ki; buna insiyaki bilgi diyorum. $\mathrm{O}$ halde rasyonel bilgi evvel emirde maddi âlemin bir bilgisidir. Ben aynı șeyi yine, rasyonel bilgiyi kendi bedenime de tatbik ederim. Fakat o zaman kendi bedenimi harici bir makine gibi telakki ederim. Harici bilgi ise canlıya müteveccihtir. Bu vücudu teșkil eden uzuvları kendisi için bir obje yapar. 
Rasyonel bilgi, maddi âleme hâkim olur. O, bunun için bazı șeyler yapmak iktizasındadır. Hâlbuki irrasyonel bilgi eșyalara dayanmaz. Bilakis vücudumuzu teșkil eden uzuvları (organları) bizzat tetkik eder. Fakat bunlar birbirlerinden ayrilmayan bilgilerdir. Bu nedenle de her rasyonel bilgi, irrasyonel bilgiyi ihtiva eder. Acaba, insan kendine hâkim olamasaydı, herhangi bir makine yapmaya imkân olur muydu? Ben kendi bedenime hâkim olmasaydım, bașka bir alet yapmaya imkân yoktur. O halde irrasyonel bilgi, rasyonel bilgiye takaddüm (öncelik) eder. İrrasyonel bilginin objeleri olan mekâna isnat eden tabiattır. Hâlbuki hadsi (sezgisel) bilginin objesi evvel emirde benim kendi hayalimdir.

İnsan aklının mahsulü olan (tekâmülün) bu șayan-1 dikkat bilgi verileri karșısında, hayvanların da insiyaki verileri bulunur. Mesela hașarat dediğimiz böceklerde, insiyaki bilgi çok inkișaf etmiștir. Mesela bir nevi sinek vardır ki; yumurtalarını kurt halinde bulunan kelebeklerin üzerine koyuyor. Bunu öyle bir mütearifane (bilgince) yapıyor ki; kelebek yavrusu öldürülmeyecek fakat yerinden de kımıldayabilecek. Çünkü hayvan ölür veya hareket ederse yumurtalar düșüp kırılabilir ve ölebilir. Kelebek yavrusu öldürülmeyecek ve kısmen hareketten mahrum kalacak.

$\mathrm{Bu}$ sinek kelebeğin yavrusunun muhtelif muayyen bir yerine iğnesini batırıyor, onu öldürmüyor. Fakat kötürüm bırakıyor. Bu sinek, sanki kelebek yavrusunun bütün anatomisini biliyormuș gibi hareket ediyor. İnsan olsaydı kelebeğin anatomisini tahlil etmeden yapamıor. Burada bir mucize bir içgüdü ile karșılașıyyoruz. Görüyorsunuz ki burada da inkișaf ve tekâmül canlı varlığa müteveccihtir. Fakat sinek için, kelebek yavrusu bașka çeșittendir. Bununla beraber sinek, bu kelebek yavrusunun vücudunun bir süre devamı ve kendi vücudunun da hayatını sürdürebilmesi için kelebek yavrusunun muayyen bir yerine iğnesini batırıyor.

Hakikaten bizim de kendi vücudumuza hâkimiyetimiz mucizedir. Sinek daha doğmadan ve daha bir kuvvete bile sahip değil iken, harekete bile bașlamadan, bașkasının vücuduna hâkim oluyor. Bu nedenle insiyakihadsi bilgi, rasyonel bilgiden nasıl ayrilır? Bu soru șöyle cevaplanabilir: Rasyonel bilgi umumi konulara teveccüh eder. Ve münferit vakıalardan umumiye, daha sonra tekrar umumiden münferit olana varır.

Bundan dolayıdır ki rasyonel bilgi bașkalarına hesap verebilir. Hâlbuki insiyaki bilgi müșahhas ve münferit olanda kalır. Mesela: sinek, muay- 
yen kelebek nevine (türüne) bir muayyen ameliye (ișlem) tatbik eder. Ben de elimi nasıl hareket ettireceğini bilirim. İnsiyaki bilgi refleksif olana tatbik edilir. Ben karșımda konușan ve jest yapan bir adamı tecrübe veya istidlal yoluyla anlayabilirim.

İște rasyonel bilgide hesap verebilirim. Hâlbuki irrasyonel olan bu bilgi münferit (tekil) olana müteveccih olduğu için, başkalarına hesap veremediğim gibi, onu aslında öğrenemem de. Bergson, her yerde bu iki bilgiyi birbirinin zıttı olarak kabul eder. Bu bilgiler șu tezada dayanır. Çünkü Bergsona göre, gayrı uzvi olan bir uzviye, șuurlar bir șuura, tekabül ediyor. Bu iki tezadın bilgisi de ayrı olur.

Filhakika biz rasyonel bilgiyi, psikolojiye de uygulayabilirdik. Ancak bunda tam muvafık olamayız. Çünkü maddi tabiatı, hendese ve fizik sayesinde tam öğrenebiliriz. Ama ne var ki, biz hayat ve șuura tesadüf ettiğimiz yerde bu rasyonel bilgiyi tatbik edemeyiz. Çünkü bu bilgi ile (rasyonel bilgi) bunların bilgisine varamayız. Çünkü hayat ve șuur insiyakın ve hadsin sahasıdır. Burada bu nevi bilgi, umumi mefhumlar teșkiline müsaade etmediği için bașkalarına da hesap verilmez. Rasyonel bilgi küllilerle ifade edilir. Hâlbuki insiyaki bilgi, küllilerle ifade edilmez. Bu bilgi bir ferde aittir.

Bergson'a göre, biyoloji ve psikoloji mevzuunu, bir madde ve makine haline koyarak tetkik eder. Bu yine Bergson'un bir fikrinden ibarettir. Ancak bu fikir müșahhas (somut) șeyler için kâfi gelmez. Filhakika, müdrike için bilinmeyen bir saha vardır ki; biyoloji ve psikoloji bu sahanın kavramlarını tetkik edebilir. Filhakika Bergson, psikolojik bilgide de ileri gidebileceğimizi kabul ederse de, bu ilerleme fizik türünden değildir.

Burada Bergson'da bilgi için bazı hudutlar (sınırlar) koyuyor. Fakat bu hudut koymasıyla Kant'tan ayrılmaktadır. Kant'ın nokta-i nazarına göre, rasyonel olmayan bilgi yoktur. Kant insiyaki bir bilgiyi kabul etmez

\section{Henri Bergson ile Hans Driesch'i Mukayese}

Geçen derste Bergson'dan bahsettik. Bergson'un iki bilgi türü ayırd1ğını biliyorsunuz. Bunlardan birincisi rasyonel bilgidir ki, fiziki ve riyazi bilgidir. Bu bilgi münferit olarak müșahede edilmeyen vakıalardan teșekkül eder. Umumi kanunlardan hareketle hususilere varır. Demek ki bu rasyonel bilgi, ilk olarak umumiyetle tecrübeye (deney); ikinci olarak da 
müșahedeye (gözlem) istinat eder. Bu bilgi sayesinde maddi tabiata hâkim olabiliriz.

Diğer yandan bu bilgi aynı zamanda diğer bir bilgi biçimi olan, hayat ve șuur bilgisine yaklașır. Fakat burada bu bilginin vazifesi biter ve yerini mümkün iradenin irrasyonel șekli olan keșfi bilgiye terk eder. Bu bilgi (irrasyonel bilgi) diğger bilginin (rasyonel bilgi) ihtiva ettiği üç özellikten de mahrumdur. Bu irrasyonel bilgi, bilmek istediği objeyi doğrudan doğruya, bir his vasitasiyla temin eder.

$\mathrm{Bu}$ iki türlü bilgiyi (rasyonel ve irrasyonel bilgi) iki nevi varlık intaç eder. Bunlardan birisi maddi ve mekanik olan ve diğeri ise, șuura ve hayata ait olan sahadır. Bunlardan ikincisi, sezgisel bilginin sahası ve ișidir.

\section{Yeni Pozitivizm Doktrini}

Şimdi yeni bir felsefe istikametine (doktrin) geçiyorum ki; bu felsefe Bergson'un zıddıdır. Bu felsefenin adı Yeni pozitivizmdir. Bunların hareket noktası olarak, sadece müșahede edilen șeyleri alıyorlar. Bu istikamete göre bilgi, ancak tabiat ilimlerinin tertip ettiği bilgi olabilir. Bergson'un zıddına bunlar tek bilgi ve tek metod kabul ederler. Bütün ilimler, tabiat ilimlerine tabidirler. Ve bu ilimler, takip ettiği ilmin üzerinde olmamalıdir.

Biyoloji ve psikoloji bilimleri, fizikten ancak onun mertebesine çıkamamakla ayrılırlar. Demek ki tek bilgi vardır. Bu bilgi de rasyonel ve riyazî prensiplere bağlı bir metot takip edebilir. Bu istikametin inkișafı fiziğe dayanmaktadır. Bu felsefe fizik ve mekanik sayesinde inkișaf etmiștir. Bundan dolayı bu felsefenin bașında birçok fizikçi görülür. Bunların başında mekanik fizikçisi olan ve aynı zamanda fizik tarihçiliği ile meșgul olan Ernest Mach gelmektedir. Bu zatın fizikteki hareket noktası fenomenolojiktir. Ernest Mach Metafiziği bile bu fenomenolojik kanunlara isnat ettiriyor.

Fakat burada șu iki fikri birbirine karıștırabilirsiniz. Fizyoloji ile fenomonoloji ayrıdır. Fizyoloji, fenomenlerden yani görülmesi mümkün șeylerden bahseder. Fenomonoloji ise bu mefhumları çok geniş olarak ele almaktadır. Mesela benim için mut'a(veri) olan șey, sadece tahtaya çizdiğim șekil değildir; bunu aynı zamanda bir mahiyet fenomeni haline getirebilirim. O halde mahiyet fenomenleri de var demektir. 
Fenomenalizm tabirinin de kısmen bununla alakası vardır. Çünkü fenomenalizmin nokta-i nazarı (bakıș açısı) fenomenler yani müșahede edilen vakıalar demektir. Müșahede edilen vakıalar ne demektir? Șu anda gördüğüm, ișittiğim șeyler fenomenin objeleri olabilir. İște fenomenalizm böyle vakaları fenomen olarak kabul eder. Zira bu kelimelere fenomenler tetabuk etmez/uygunluk göstermez.

Hâlbuki fenomonoloji, umumi fenomenleri de veri haline getirebileceğini söyler. Mesela șu fenomeni bir veri haline getirebiliriz. Bunu yapabilmem için münferit bir fenomenin bulunması șarttır. $O$ halde, münferidin hareketini umumiye yükseltelim ve onu veri haline getirelim. Yalnız münferit vakalar değil, aynı zamanda umumi fenomenler de mevcuttur. Hâlbuki fenomenalist görüșe göre, sadece müșahede edilebilen vakıalar vardır; umumi fenomen diye bir șey yoktur.

Fenomenalistlerin hareket noktaları aynı olmasına rağmen ayrı neticelere varıyorlar. Fenomenolojistlere göre, fenomenler vakıaların gözlemleridir. Bunlar için ancak gözlemlerin temin ettiği vakıalar fenomendir. Fenomenolojistler için fenomen daha umumi iken; Mach'a göre fizyoloji tek bașına gözlenebilen vakalarla teșkil olur.

Filhakika buna itiraz edilebilir. Fiziğin konusu atomlardır. Eğer "deniz, dalgaların hareketleridir" denirse, bunlar nasıl müșahede (gözlem) objeleri olabilir? Bu birbirine zit kuvvetler nasıl müșahede edilebilir? Mach, bu itiraza șu cevabı verir. Bu birbirine zıt kavramlar, fiziğe yardımc1 kavramlardır. Fizik bunlardan istifade eder. Fiziğin ilgisi üzerine müșahede edilen objelerdir. Eğer fizik dalgadan, atomdan hareketlerden bahsediyorsa, bunlar yardımcıdır.

Fizik sanki bunlardan teșekkül ediyormuș farz edilir. Fizik vakaları tahlil eder. Parçalara ayırır. Bu pozitivist bir nokta-i nazar (bakıș açısı)dır. Pozitivizmin objesi, mevcut olan, müșahede edilen objelerden ișittiğimiz, gözümüzle gördügümüz șeylerdir. Bu vakaları bir araya getirmek, bunları kanunlaștırmak, bu defa șu istikamette cereyan eder demek, ancak ilmin vazifesidir. Bunu temin için, mecmu(toplayıcı) karakterini haiz kavramlar kullanır. Kavramlar isimlerdir. Bir kavrama, müșahede olanları dâhil ederiz.

Bundan bașka ilim kanun manasında șeyleri bulmaya çalıșır. Mesela: 
Tabiat ilimleri eser ve illetler(sebep)den bahseder. Fakat bundan șu anlașır. Yani, illet-eser (sebep-sonuç) demek fenomenler arasında bir bağlantının, bir fenomen grubunun, diğer biriyle bağlı olduğunu göstermek demektir. Eğer bu fenomenlerden belirli bir grup veri haline geldiği takdirde, diğgerinin de az çok veri haline geleceği kabul edilir. Her ilmi iddia bu șekilde herhangi bir șeye irca edilmelidir. Bu esas fikrin dișında kalan ve fenomenleri aşan her iddia geçerli olmaz. Fenomenleri aşan kavramlar ancak yardımcı kavramlar olabilir. Bizim kabul edebileceğimiz șey ancak veri halinde olandır.

Mach'a istinad ederek, bu doğrultuda çalıșanlar, bu maddelere daha kesin bir șekil vermeye çalıșırlar. Bunların iddiası da bir kaziyenin (önermenin) manasını tespit etmek onun tahkiki için bir metot bulmak demektir. Bunu bir misalle açıklamaya çalıșalım. Bir obje hakkında "bunun uzunluğu üç metredir" diyorum. Bu kaziyenin manası nedir? Herkes bunu anlıyor. Bunun manası üç metreyi hatırlamaktır. Fakat bu Yeni Pozitivistler için kesin midir? Değildir. Çünkü onlara göre, bir kaziyeyi tahkik için nasıl bir metot kullanırız? Bunun için evvela bir metre kullanırız. Ve metreyi üç defa bu șeye tatbik etmek lazımdır. Metre, öyle bir uzunluktur ki, belirli manalara maliktir. Ondan beklediğimiz vazifelerin temin olması icap eder. Metre öyle bir uzunluktur ki, belirli faydalara göre imal edilmiștir. Demek ki bunun(metrenin) vazifeleri söylediğimiz manayı ihtiva etmelidir.

Metre ile bir uzunluk temin edebilirim. Fakat șekilde bunu söyleyemem. Demek ki, uzunluk hakkındaki bütün iddialar, o basit kaziyeyi temin etmektedir. Bunlar, tecrübeyle tahkik edilmeyen fenomenlerdir. İtibari (göreli) olarak geçerlidir. Demek ki bir șeyi tahkik ederken tecrübeyle tahkik edebiliriz. Ayrıca bunu ayırmak lazımdır. Görüyorsunuz ki bu basit kaziyelerde bile ummadığımız bazı tecrübe ile kabil-i tahkik olan ve olmayan birçok iddialar temin ediyor.

O halde filozofların dediği nazariyenin vazifesi nedir? Bilgi nazariyesinin vazifesi; tetkik ettiğimiz șeylerin hangisinin tecrübe ile tahkik edebildiğimiz, hangisinin (konvansiyonel) ve itibari olduğunu anlamak konusunda yardımcı olmaktır. Bu nevi itibari mefhumlar ne doğru, ne de hatalidır. Bunlar bilgimize sistem veren șeylerdir. Bu türden olan itibari mefhumlar değișebilir. Çünkü bilginin sistemi de değișebilir. Demek ki bir 
tarafta tecrübe, diğer tarafta konvansiyon vardır.

Șimdi bizi modern fiziğe yaklaștıran diğer bir misal alalım. Șöyle bir iddia ortaya atıyorum. Bütün vak'alar aynı zamanda cereyan ediyor. Vukuu mümkün olan her șey (bu tek zaman) içinde cereyan ediyor. Vaki olan șey aynı zamanın muayyen bir noktasında bulunur. Burada tahkik edilen için, itibari olan hangisidir. Tahkikimi cereyan eden bir zamana nispet edebilirim. Ama zamanın kendisinin her noktasının aynı olduğunu ölçemem.

Șu halde farklı noktalarla cereyan eden zaman kaziyesi, bir konvansiyondur. Aynı zamanda benim ölçtügüm muhtelif zamanlardır. Ve bu zaman noktalarının devamını saatle ölçebilirim. Saat nedir? Zaman ölçer. Eğer saatlerin ölçtüğü dünyanın hareketi bazen yavaș, bazen daha süratli olsaydı ben onu zaman ölçmede kullanamazdım. O halde periyodik hareketin birbirine müsavi olması lazımdır. Fakat bunu nasıl tespit ediyoruz. Misal: dünyanın, güneș etrafındaki hareketiyle bir zaman kat' ettiğini nasıl tespit edebiliriz. Bugün diğerinin aynıdır veya değildir. Biz bunu ölçüye göre yaparız. Görüyorsunuz ki, burada bir konvansiyonele mecbur kalıyoruz. Demek ki tetkik ettiğimiz șeylerde iki kavram vardır: a-tecrübe ile tahkik edilebilenler; b-konvansiyonlar.

Filhakika biz bunları tecrübe ile tahkike çalıșıyoruz. Kullandığımız saatler ki, bir konvansiyonun tertibidir. Çünkü biz bunu doğrudan doğruya tecrübe ile tahkik edemeyiz. Fakat bunların üzerine kurulacak sistem daima tecrübe ile kabil-i tahkiktir(araștırılması mümkündür). Tekrar ediyorum ki, bilgi nazariyesinin vazifesi bu fikirlerden hangi tarafı kabil-i tahkik ve hangisi itibaridir? Ve bu konvansiyonlardan hangisinin, bilginin tahkikine delalet ettiğini tespit etmektir.

Modern fizikteki hem-zaman ve mekânı örnek olarak ele alalım. İki vakıa aynı zamanda vukua geliyorlar. Yani hem-zamandır. Mesela: bir astronom teleskopla bir yıldızın muayyen noktasına geldiği zaman, saatin rakkasının (zil) çalması hem-zamanlıktır. Fakat bundaki hem-zamanlık bir müșahede vakıasıdır. Hem-zamanın evvelinde iki vakıa lazımdır. Müșahede için iki mekânın aynı zamanda olması mut'a (veri) halindedir.

Şimdi bu verdiğimiz hem-zamaniyet örneğini bașka vakıalara tatbik edelim. Muayyen bir vakıa günește ve muayyen bir vakıa arzda aynı za- 
manda cereyan ediyor. Bu ikincisi aynı derecede bir vuzuhu (açıklığı) ihtiva eder mi? Fizikçi șöyle söyler: eğer tam manasıyla dikkat edersem bunlar vazıh(açık) değildir. Çünkü buradaki hem-zamaniyet müșahede neticesi değildir. Hem-zamaniyeti tespit için vazıh (açık) olanlara ihtiyaç gösterir.

Daha basit bir misal: Amerika'daki New York ile İstanbul'daki vakıaları ele alalım: İstanbul'daki müșahid (gözlemci) bunu (Amerika'daki olayı) ispat edebilir mi? Edemez. Çünkü ancak kendi gördügünü müșahede edebilir. New York'tan bunlar hakkında aynı neviden vakıa olduğuna dair haber alıyor. Böylece hem-zamaniyeti ispat için müșahit her ikisini de görüyor. Ve saat üzerinde ispat edebiliyor. Her iki saat de aynı zamanı göstermelidir.

Eğer bu müșahitlerden birinin saati geri kalırsa aynı zamanı ispat edemezler. Rakamların müsavi olması lazımdır. Bunu için bir ișarete ihtiyaç vardır. Mesela, New York'taki kiși müșahede ettiği hadiselerin zamanı anında İstanbul'a hemen telgraf çekiyor. Fakat bu ișaretin süratini de bilemeyiz. Bu sürati ölçmek, elektrik dalgasını, ziyayı (ıșı) ölçmek demektir. Tecrübe bize her iki tarafın aynı suretle malik olduğunu gösterir.

Görüyorsunuz ki hem-zamaniyet ve nispet meselesine çeşitli iddialar dâhil edilmektedir. Aynı zamanda müșahite kendi aletini kullanması da şart koșulmuștur. O halde fizikçi de müșahedelerinin mevzu olan dünya hakkında, kendi aleti ile dolașan müșahidi șart koșar. Bu alet sayesinde muayyen kaideler, faraziyelerden istifade ederiz. Bu aleti imal için bazı iddialar ileri sürülür. Bunlardan bir kısmı teyit edilebilir veya edilemez. Ve bunların hepsi itibaridirler. Konvansiyonların tahkiki için, onlarla beraber, aynı zamanda gereken șeyler vardır: tecrübe ile tahkik.

Görüyorsunuz ki bu yeni pozitivizm evvela Avrupalı bir ilim kurmak istiyor. "Bir vakıanın hakikat ve hatasını (doğruluğunu ve yanlıșlığını) tecrübe ile tahkik eylemeliyiz" diyorlar. Pozitivizm aynı zamanda bilgi sistemimizin de tecrübe ile tahkik edilmesinin gerekli olduğunu inanyor. Hatta itibari olan șeyler bile tecrübe edilebilmelidir ki, bir bilgi sistemine varılabilsin. İlmin evvela bilmek için, böyle bir metodu takip etmesi lazimdir.] 
Öz: Bu çalıșma 2o. asır Alman felsefe tarihçisi Ernst von Aster hakkında kısa bir biyografik bilgi ve onun 1943-1944 eğitim öğretim döneminde İstanbul Üniversitesi, Edebiyat Fakültesi, Felsefe șubesinde vermiş olduğu "Çağdaș Felsefe" ders notlarından olușmaktadır. Söz konusu dönemdeki felsefe öğrencilerinden Cahit Tanyol'un Osmanlı Türkçesi ile tuttuğu notlardan olușan metin, Latin alfabesine çevrilerek, yayınlanmaya hazır hale getirilmiștir. Bu dersler, Descartes'in felsefesi özellikle varlık anlayıșından bașlamaktadır. Bundan sonra Descartes ile Newton'un evren ve mekanik hakkındaki fikirleri karșılaștırılmaktadır. Peșinden Newton fiziği ve Kant'ın felsefesi arasındaki ilișkiler incelenmektedir. Daha sonra Kant metafiziği ile Brentano'nun felsefesi karșılaștırılmaktadır. Yeni Kantçılık ve Schelling ilişkisinden sonra, Kant'ın Husserl ile karșılaștırılmasiyla devam eder notlar. Ayrıca Heidegger'in ontolojisinde önemli kavramlar zaman ve mekân kavramları anlatılırken, Descartes ile Heidegger'in varlık anlayıșı karșılaștırılır. Son olarak Hans Driesch'in vitalizmi ve Bergson'un spritüalizmi anlatılmaktadır. Bergson'un ve Darwin'in evulusyon anlayıșlarının karșılaştırılmasından sonra notlar, Yeni Pozitivizm konusu ile bitmektedir.

Anahtar Kelimeler: Ernst von Aster, ders notları, çağdaș felsefe, fizik, varlık. 
业 